\title{
1 Methane as a carbon source for the food web in raised bog pools
}

2

3 G.A. van Duinen ${ }^{1,2,3}$, K. Vermonden ${ }^{1,3}$, P.L.E. Bodelier ${ }^{4}$, A.J. Hendriks ${ }^{3}$, R.S.E.W. Leuven ${ }^{3}$,

4 J.J. Middelburg ${ }^{5,6}$, G. van der Velde ${ }^{2,7}$ \& W.C.E.P. Verberk ${ }^{1,2}$

5

$6 \quad{ }^{1}$ Bargerveen Foundation / Radboud University Nijmegen, P.O. Box 9010, 6500 GL

$7 \quad$ Nijmegen, The Netherlands

$8{ }^{2}$ Radboud University Nijmegen, Institute for Water and Wetland Research, Department of

9 Animal Ecology and Ecophysiology, P.O. Box 9010, 6500 GL Nijmegen, The Netherlands

$10{ }^{3}$ Radboud University Nijmegen, Institute for Water and Wetland Research, Department of

11 Environmental Science, P.O. Box 9010, 6500 GL Nijmegen, The Netherlands

$12{ }^{4}$ Netherlands Institute of Ecology (NIOO-KNAW), Department of Microbial Ecology, P.O.

13 Box 50,6700 AB Wageningen, The Netherlands

$14{ }^{5}$ Utrecht University, Faculty of Geosciences, Department of Earth Sciences - Geochemistry,

15 P.O. Box 80.021, 3508 TA Utrecht, The Netherlands

$16{ }^{6}$ Department of Ecosystem Studies, Royal Netherlands Institute for Sea Research (NIOZ),

17 Korringaweg 7, 4401 NT Yerseke, The Netherlands

$18{ }^{7}$ Naturalis Biodiversity Center, P.O. Box 9517, 2300 RA Leiden, The Netherlands

20 E-mail: G.vanDuinen@science.ru.nl 
Raised bog pools are extremely nutrient poor and rich in humic substances, limiting primary production. To assess the base of the invertebrate food web in bog pools stable isotopic signatures of primary producers, dead organic matter, and invertebrates, as well as the composition and stable carbon isotope ratio of phospholipid fatty acids (PLFAs) were measured. The stable isotopic signatures showed the presence of multiple trophic levels and a differential use of basal food sources by the invertebrates, both between different species and within species, among different individuals and size classes. Carnivorous and omnivorous invertebrates assimilated polyunsaturated fatty acids (PUFAs) derived from algae, and possibly macrophytes, as well as fatty acids that are specific for methane oxidizing bacteria (MOB). A considerable part of the bacterial biomass conveyed to higher trophic levels in the bog pools likely originates from MOB. Protozoa and zooplankton synthesizing PUFAs commonly used as biomarkers for algae may play a role in this pathway. Pelagic zooplankton seems to rely more on bacteria, whereas for insects algae are more important. Periphyton was the basal food source most depleted in ${ }^{13} \mathrm{C}$ and inferred to sustain at least half the food web. The relatively depleted $\delta^{13} \mathrm{C}$ values of PUFAs in invertebrates point to the use of algae that possibly derived carbon from MOB. Therefore, depleted $\delta^{13} \mathrm{C}$ values of invertebrates do not necessarily implicate a direct pathway between $\mathrm{MOB}$ and these invertebrates, but algal food sources forming an intermediate level.

Keywords: peatland, algae, methane oxidizing bacteria, zooplankton, insects, stable isotopes, 44 fatty acids 
Heterotrophic organisms are sustained by living or dead biomass. This organic matter can be locally produced or imported from elsewhere. In pristine raised bogs, primary production is strongly nutrient limited and the nutrient content of the dominant Sphagnum mosses and vascular plants is extremely low (Aerts et al. 1999). Pools are a significant feature of raised bogs (Belyea and Lancaster 2002), harbouring a large biodiversity of aquatic macroinvertebrates (Desrochers and Van Duinen 2006, Verberk et al. 2006). In these pools

55 primary production by submerged macrophytes and algae is further constrained by low levels of light, resulting from a high concentration of humic substances (Karlsson et al. 2009). As a consequence of the low nutrient content of living and dead organic matter in bog pools, consisting mostly of mosses and vascular plants, the decomposition rate of dead organic matter is very low, something which is compounded by the acidic conditions in raised bogs (Belyea 1996, Smolders et al. 2002). The limited primary production and low nutritional

61 value of living and dead plants give rise to the question what basal food sources sustain the food web in raised bog pools. Run-off water providing organic carbon sources could potentially provide another basal food source to sustain the food web in raised bog pools. In lakes, the relative importance of these allochthonous organic carbon sources to the food web increases with decreasing lake trophy and decreasing phytoplankton production (Grey et al. 2000, Pace et al. 2007). Contrary

67 to lakes and streams, raised bog pools are isolated from other water bodies and do not have a large catchment area that could supplement the food web with allochthonous organic carbon and other nutrients. Bog pools are embedded in peat, constantly releasing humic substances. Concerning bog pools, Rydin and Jeglum (2006) suggested bacteria feeding on dissolved

71 humic substances as a second basal food source, in addition to photosynthesis. Jones (1992) 
72 described humic substances as an important carbon source in planktonic food chains in lakes

73 in which primary production of algae is limited by oligotrophy or humic substances. Although

74 humic substances are highly recalcitrant to microbial degradation, Tranvik (1988) found that

75 lakes with a high content of humic substances could support a higher bacterial biomass than

76 clearwater lakes due to their larger pools of dissolved organic carbon (DOC).

77 Biogenic methane could be a third basal carbon source. In bogs methane is produced

78 during the decomposition of peat (Raghoebarsing et al. 2005). Methane-derived carbon can

79 contribute to the food web via methanotrophic bacteria, which are found to be ingested by

80 zooplankton (Bastviken et al. 2003, Taipale et al. 2007), chironomid larvae (Jones et al.

81 2008), and caddisfly larvae grazing their own cases (Trimmer et al. 2009).

82 A powerful tool to distinguish between the potential food sources and to determine the

83 configuration of food webs is dual stable isotope analysis $\left(\delta^{13} \mathrm{C}\right.$ and $\left.\delta^{15} \mathrm{~N}\right)$ of producers and

84 consumers. This approach is based on a predictable change in the natural abundance stable

85 isotopes composition between the different trophic levels (DeNiro and Epstein 1978,

86 Minagawa and Wada 1984) and has been applied in a wide range of ecosystems. However,

87 the extent to which the pathways conveying organic matter to consumers and their predators

88 can be inferred solely from stable isotopic signatures depends on the variation and

89 distinctness of the isotopic signatures of basal food sources. In addition, the isotopic signature

90 of a consumer can result from the consumption of a single food source, but more realistically

91 from the consumption of a mixture of two or more food sources. One way to gain a better

92 understanding of the relative importance of basal food sources in food webs is to combine the

93 analysis of natural abundance stable isotopes composition with analyses of phospholipid-

94 derived fatty acids (PLFAs) composition (Kharlamenko et al. 2001, Perga et al. 2006, Van

95 den Meersche et al. 2009). The approach using PLFAs is based on the specific PLFA 
composition of bacteria and algae and on the inability of animals to synthesize specific

PLFAs and essential polyunsaturated fatty acids (Kharlamenko et al. 2001).

To our knowledge, Kato et al. (2010) and Van Duinen et al. (2006a) performed the

only food web studies applying stable isotopes analyses in a temperate bog. Kato et al. (2010)

focussed on a hummock-hollow complex rather than raised bog pools. Interestingly, both

studies highlighted a missing basal carbon source. Kato et al. (2010) found dead leaf stalks of a dominant vascular plant (Menyanthes trifoliata) and benthic particulate organic matter to be the most likely potential food sources for aquatic and terrestrial detritivores, but aquatic predators seemed to rely also on another unknown basal food source, enriched in ${ }^{13} \mathrm{C}$ compared to the benthic particulate organic matter. In our previous study in raised bog pools (Van Duinen et al. 2006a) we inferred that the missing basal carbon source should be more depleted in ${ }^{13} \mathrm{C}$ compared to the living macrophytes, filamentous algae and dead organic matter present in these pools, but we were unable to verify its identity. This depleted food source could be based on methane, which is the only component carrying a very negative $\delta^{13} \mathrm{C}$ value (Boschker and Middelburg 2002). The role of methane in freshwater food webs has recently attracted much attention (Jones and Grey 2011).

Here, we revisit the enigma of a missing basal carbon source and investigate the food web of three pools in the raised bog Nigula, Southwest Estonia, by means of analysis of both stable isotopes and PLFAs to assess if this food web is sustained by the primary producers that dominate the plant biomass in these pools (the macrophytes Sphagnum mosses and vascular plants), their dead organic matter, and dissolved organic substances, or that algae, or methanotrophic bacteria contribute to the food web, as well. Specifically, we address the following questions: 
119 1. Do the isotopic signatures of the aquatic invertebrates of different trophic levels indicate

120 use of macrophytes, their dead organic matter, dissolved organic substances, algae, or other

121 basal food sources?

122 2. Can the PLFA composition of aquatic invertebrates be used to infer the trophic pathways in

123 the food web in raised bog pools?

124 
Study area

The three bog pools (N1, N2 and N3) were situated in the pristine raised bog massif of

129 Nigula Nature Reserve, Southwest Estonia (Fig. 1). At each of the three pools samples of 130 surface water, sediment pore water and sedimented organic matter (SOM) were collected in

131 May 2001 and September 2002 to assess $\mathrm{pH}$ and the concentrations of nutrients and other 132 components. For further details about the methods used for analyses see Van Duinen et al. 133 (2003, 2006b). The concentration of dissolved organic carbon (DOC) in surface water was 134 analysed in samples collected in December 2006 and July 2007. For each pool nutrient 135 content and other background data are presented as averages of the two sampling periods 136 (Table 1).

Sampling and analyses of stable isotope ratios

Plants (filamentous algae, mosses and vascular plants) and aquatic macroinvertebrates were collected in September 2002 at the three pools. SOM was collected from the peat bottom

141 by means of a plankton net with mesh size $45 \mu \mathrm{m}$. Zooplankton was collected from the open

142 water by means of a plankton net with mesh size $115 \mu \mathrm{m}$ and light traps. As an additional

143 potential source to aquatic invertebrates, invertebrates flying and walking around the bog

144 pools and eventually drowning in the pools, were collected in August 2006. Periphyton

145 (mainly consisting of algae) was collected by scraping from plastic sheets after rinsing with

146 demineralised water. These sheets $(30 \times 25 \mathrm{~cm})$ hung vertically in the water bodies for one

147 month in August-September 2007 with their upper end close to the water surface. In these

148 pools fishes do not occur and amphibians are rare. Gut contents were not removed from

149 invertebrates, as trials with several species showed that they did not empty their guts within 
two or more days of living in filtered surface water of bog pools. Collected invertebrates were

151 sorted, washed with demineralised water and kept in a fridge until identification to species or

152 genus level. Identified material was dried for 24 hours at $70^{\circ} \mathrm{C}$ and subsequently ground,

153 using liquid nitrogen. Large macroinvertebrates were analysed individually, whereas smaller

154 individuals were pooled per species. Carbon and nitrogen isotopic composition of each

155 sample was determined in duplo or triplo with a Carlo Erba NA 1500 elemental analyzer

156 coupled online via a Finnigan Conflo III interface with a ThermoFinnigan DeltaPlus mass-

157 spectrometer.

158 Surface water samples for analysis of the $\delta^{13} \mathrm{C}$ value of DOC were collected in

159 December 2006 and July 2007 by filtering surface water over a filter with mesh size $0.2 \mu \mathrm{m}$

160 (Schleicher \& Schuell FP 030/3) and adding $100 \mu \mathrm{L} \mathrm{50 \%} \mathrm{H}_{3} \mathrm{PO}_{4}$ to $40 \mathrm{~mL}$ water sample. The

161 carbon isotopic composition of dissolved organic carbon has been measured using a high-

162 performance-liquid-chromatograph coupled via a LC-Isolink interface to an isotope-ratio

163 mass spectrometer (Delta V Advantage IRMS, Thermo). The technique of the Isolink

164 interface is based on the wet oxidation of organic analytes with peroxodisulfate under acidic

165 conditions. The $\mathrm{CO}_{2}$ produced is subsequently separated from the mobile phase in a capillary

166 gas exchanger flushed with helium gas, dried before introduction into the IRMS (Boschker et

167 al. 2008).

168 Stable isotope data are presented as the relative difference between the ratios of the

169 sample and the standards, using the following formula:

$171 \delta \mathrm{R}=\left[\left(\mathrm{R}_{\text {sample }} / \mathrm{R}_{\text {standard }}\right)-1\right] \times 1000$

172

173 where $\mathrm{R}={ }^{13} \mathrm{C} /{ }^{12} \mathrm{C}$ or ${ }^{15} \mathrm{~N} /{ }^{14} \mathrm{~N} . \delta^{13} \mathrm{C}$ or $\delta^{15} \mathrm{~N}$ is the per mille (\%o) deviation of the sample from

174 their isotope standards, that are Vienna PeeDee belemnite for $\delta^{13} \mathrm{C}$ and atmospheric $\mathrm{N}_{2}$ for 
$175 \delta^{15} \mathrm{~N}$. Average reproducibility based on replicate measurements of samples and internal

176 standards Sucrose (IAEA-CH-6) for $\delta^{13} \mathrm{C}$ and Ammonium sulphate (IAEA-N-2) for $\delta^{15} \mathrm{~N}$ was

$177<0.2 \%$.

178

Estimation of the contribution of basal carbon sources

180 We estimated the feasible contributions of the different potential basal carbon sources

181 (SOM, DOC, submerged Sphagnum, vascular plants, filamentous green algae, and

182 periphyton) for each trophic group of invertebrates by means of isotope mixing models for

$183 \delta^{13} \mathrm{C}$ to get an indication of the contribution of these carbon sources in sustaining the higher

184 trophic levels. Invertebrates were classified in trophic groups according to Nilsson (1996,

185 1997) and references therein, Vallenduuk and Moller Pillot (2007), Moller Pillot (2009), and

186 Higler (2005). For each group of basal carbon sources and each trophic group of invertebrates

187 (carnivores, omnivores, and herbi-detritivores; the latter including species classified as

188 herbivores, detritivores and herbi-detritivores) the average $\delta^{13} \mathrm{C}$ value was calculated and used

189 as input to the mixing model. We used IsoSource version 1.3.1 (Phillips and Gregg, 2003),

190 creating all possible combinations of proportions of the six potential basal carbon sources,

191 with increments of these proportions set at $1 \%$. Combinations that sum to the average $\delta^{13} \mathrm{C}$

192 value of the trophic group within a tolerance of $0.1 \%$ were considered to be feasible

193 solutions. We assumed trophic fractionation to be negligible.

194

195 Lipid analyses and stable isotope analysis of PLFAs

196 SOM, pelagic zooplankton, and several mostly carnivorous insect species were

197 collected in the pools in August 2006 and subsequently freeze dried and ground. Benthic

198 macrofauna was removed from the SOM samples. Lipid analyses and stable isotope analyses

199 of PLFAs were performed as described by Mohanty et al. (2006). Lipids were extracted from 
$0.5 \mathrm{~g}$ of the sedimented organic matter and $0.1 \mathrm{~g}$ of the invertebrate material with a Bligh-

201 Dyer extraction procedure as modified and described by Boschker et al. $(1998,2001)$. The

202 lipid extract was fractionated on silicic acid into different polarity classes by sequential

203 elution with chloroform, acetone, and methanol. The methanol fraction containing the PLFA

204 was derivatized using mild-alkaline methanolysis to yield fatty acid methylesters (FAME).

205 FAME standards of both C12:0 and C19:0 were used for calculating retention indices and for

206 FAME quantification. Identification of FAME was based on retention time data with known

207 standards. Additional identification was gained by GC-mass spectrometry (GC-MS) using a

208 Thermo Finnagan TRACE GC-MS system. For identification of methanotroph-specific

209 PLFA, extracts of cultures of Methylomonas methanica S1 NCIMB 11130,

210 Methylomicrobium album NCIMB 11123, Methylobacter luteus NCIMB 11914,

211 Methylocystis parvus NCIMB 11129, Methylosinus trichosporium NCIMB 11131, and

212 Methylosinus sporium NCIMB 11126 were used as references. PLFA nomenclature used is as

213 described by Guckert et al. (1985). PLFAs are designated by the number of carbon atoms. The

214 degree of unsaturation is indicated by a number separated from the chain length by a colon.

215 This number is followed by $\omega x \mathrm{xc}$ or $\omega \mathrm{xt}$, where $\mathrm{x}$ indicates the position of the double bond

216 nearest to the aliphatic end $(\omega)$ of the molecule and $\mathrm{c}$ and $\mathrm{t}$ indicate $\mathrm{a}$ cis and trans

217 stereoisomeric position of the double bond on the molecule. The prefixes i and a refer to iso

218 and anteiso branching. The prefix $10 \mathrm{Me}$ refers to methyl branching at the $10^{\text {th }}$ carbon from the

219 carboxyl group. The prefix br indicates an unknown branching. The prefix cy refers to

220 cyclopropyl rings. PLFAs with unknown molecule structure are referred to using the

221 equivalent chain length (ECL) expressing their retention time relative to those of known

222 straight-chain saturated FAME.

223 FAME concentrations were determined using a GC-FID system (Thermo Finnagan

224 TRACE GC) equipped with a polar capillary column (SGE, BPX-70; $50 \mathrm{~m}$ by $0.32 \mathrm{~mm}$ by 
$0.25 \mu \mathrm{m})$, using the following oven conditions: initial temperature of $50^{\circ} \mathrm{C}$ for $1 \mathrm{~min}$, and

226 then the temperature was programmed to $130^{\circ} \mathrm{C}$ using a ramp of $40{ }^{\circ} \mathrm{C} \min ^{-1}$ followed by an

227 increase to $230{ }^{\circ} \mathrm{C}$ with a ramp of $3{ }^{\circ} \mathrm{C} \mathrm{min}^{-1}$.

228 Stable carbon isotope ratios for individual FAME were determined using a Varian

$2293400 \mathrm{GC}$ equipped with an ATAS Optic 2 programmable direct thermal desorption injection

230 system. The GC was coupled via a type II combustion interface to a Finnigan Delta S isotope

231 ratio mass spectrometer. The same polar capillary column was used as for FAME

232 identification and quantification on the GC-FID and GC-MS systems. The oven temperature

233 for the GC-isotope ratio mass spectrometry analyses was as follows: initial temperature of

$23450^{\circ} \mathrm{C}$ for $4 \mathrm{~min}$, and then the temperature was programmed to $130^{\circ} \mathrm{C}$ using a ramp of $30^{\circ} \mathrm{C}$

$235 \mathrm{~min}^{-1}$, which was immediately followed by an increase to $200^{\circ} \mathrm{C}$ using a ramp of $6^{\circ} \mathrm{C} \min ^{-1}$, a

236 subsequent increase to $220^{\circ} \mathrm{C}$ using a ramp of $5^{\circ} \mathrm{C} \min ^{-1}$, and a final increase to $250^{\circ} \mathrm{C}$ using a

237 ramp of $20^{\circ} \mathrm{C} \mathrm{min}^{-1}$. The sample was injected into the direct thermal desorption system at

$23850^{\circ} \mathrm{C}$, after which the temperature was programmed to $260^{\circ} \mathrm{C}$ with a ramp of $10^{\circ} \mathrm{C} \mathrm{s}^{-1}$.

239 PLFAs with a relative concentration $<0.1 \%$ are disregarded. $\delta^{13} \mathrm{C}$ values of PLFAs

240 with a relative concentration $<1 \%$ are regarded as unreliable and not presented here. The

241 potential affiliated biota of the PLFAs found in SOM and invertebrates was taken from

242 Boschker and Middelburg (2002), Dijkman and Kromkamp (2006) and Taipale et al. (2009),

243 accomplished with various other papers mentioned in the results and discussion sections. 
Stable isotopic signatures

248 The various invertebrate species collected in the three bog pools differed in their $\delta^{13} \mathrm{C}$ values (Table 2), indicating a differential use of basal carbon sources, and in their $\delta^{15} \mathrm{~N}$ values, indicating the presence of multiple trophic levels (Fig. 2). The living and dead plant material showed the lowest $\delta^{15} \mathrm{~N}$ values. Most aquatic invertebrate species collected were carnivorous according to literature (Table 2). The highest $\delta^{15} \mathrm{~N}$ values, in the range of 1.2 to $10.3 \%$, were found for the heteropterans Notonecta glauca, Nepa cinerea and Ranatra linearis, the water spider Argyroneta aquatica, and the coleopterans Dytiscus dimidiatus, Dytiscus lapponicus, Acilius canaliculatus and Acilius sulcatus, which are known to be top-predators. The $\delta^{15} \mathrm{~N}$ values of corixid species and dipteran, dragonfly, damselfly, mayfly, and caddis fly nymphs and larvae ranged between -2.0 and $2.8 \%$. The invertebrates with the lowest $\delta^{15} \mathrm{~N}$ values were

258 found among the invertebrate species known as herbivores, herbi-detritivores or omnivores, 259 e.g. zooplankton in pool N1 (dominated by the microcrustaceans Bosmina spec., Chydorus sphaericus and copepodites), Leptophlebia vespertina nymphs in pools N2 and N3, and larvae of the chironomid genera Psectrocladius and Chironomus in pools N1 and N3. Individuals of the large predatory invertebrate species Acilius canaliculatus, Acilius sulcatus, Dytiscus dimidiatus, Dytiscus lapponicus and Notonecta glauca were analysed

264 separately. Various individuals of the same species captured in the same water body differed 265 strongly in isotopic signature for both $\mathrm{C}$ and $\mathrm{N}$ (Table 2).

266 Many of the invertebrates were more depleted in ${ }^{13} \mathrm{C}(<-28 \%)$ than the dominant 267 primary producers (vascular plants, mosses, filamentous and branched green algae), their dead 268 organic matter, and DOC (Fig. 2). Periphyton (mainly consisting of green algae) was the most 269 depleted potential basal carbon source found. The periphyton varied considerably in their $\delta^{13} \mathrm{C}$ 
270 values between the three bog pools (Table 2). The lowest $\delta^{13} \mathrm{C}$ value of periphyton, found in

$271 \mathrm{~N} 3(-34.69 \%)$, could account for the $\delta^{13} \mathrm{C}$ value of at least the more depleted half of the

272 invertebrate food web, assuming an enrichment (less negative) of 0 to $1 \%$ for the $\delta^{13} \mathrm{C}$ values

273 between trophic levels (e.g. Post 2002, McCutchan et al. 2003). The mixing models indicated

274 that periphyton contributes on average 55\% to the trophic group of the carnivores and at least

$27544 \%$ (1\% percentile), and a bit less in the case of the omnivores and herbi-detritivores. The

276 contribution estimated for the other potential basal carbon sources was considerably lower

277 (Table 4). For zooplankton the feasible contribution was not assessable as their $\delta^{13} \mathrm{C}$ was more

278 depleted than those of the potential basal carbon sources.

279 The $\delta^{13} \mathrm{C}$ values of invertebrates flying and walking around the bog pools exceeded -

$28028 \%$, with the exception of several imagines of Trichoptera, Nematocera, and the damselfly

281 Enallagma cyathigerum (Table 3), whose aquatic larvae or nymphs have developed in the bog

282 pools. The $\delta^{15} \mathrm{~N}$ values of many of these invertebrates collected around the pools overlapped

283 with those of the aquatic invertebrates. Assuming a trophic enrichment (less negative) of

284 about 3\%o for the $\delta^{15} \mathrm{~N}$ values (according to Minagawa and Wada (1984) and Post (2002) and

285 confirmed by the average $\delta^{15} \mathrm{~N}$ values of the trophic levels in this study (Fig. 2)) and of 0 to

$2861 \%$ for the $\delta^{13} \mathrm{C}$ values, it is unlikely that these invertebrates are a major component in

287 sustaining the aquatic food web.

\section{PLFA composition and stable carbon isotope ratio}

290 The PLFAs characteristic for methane oxidizing bacteria type I (MOB I: 16:1 $18 \mathrm{c}$ and

291 16:1 15 t; Nichols et al. 1985, Bowman et al. 1993) were found in SOM and all invertebrates

292 (Table 5), but at low concentrations. The $\delta^{13} \mathrm{C}$ values of these PLFAs could not be measured

293 because of these low concentrations (about $1 \%$ of the total amount of PLFA or less). The

294 PLFA 18:1 $18 \mathrm{c}$, characteristic for MOB II (Bodelier et al. 2009), was found in SOM and had a 
$295 \delta^{13} \mathrm{C}$ value of $-38.0 \%$ (Table 6 ). This PLFA was not detected in the invertebrates. Here, it

296 must be noted that in the PLFA analysis of the invertebrates the high peak of the PLFA

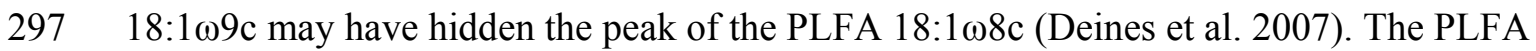

$29818: 1 \omega 9 \mathrm{c}$ was present in high concentration in all invertebrates and in a lower concentration in

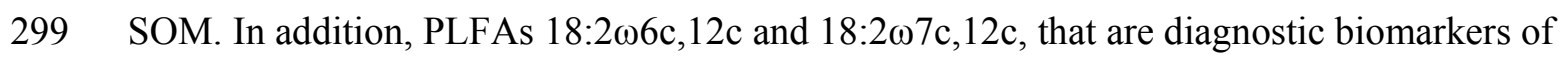

300 Methylocystis strains (MOB II) according to Bodelier et al. (2009), were detected in SOM and

301 two insect species.

302 Methyl-branched and branched unsaturated PLFAs that are typical for sulphate-

303 reducing Bacteria and Actinomycetes (Kroppenstedt 1992, O’Leary and Wilkinson 1988)

304 were found at low concentrations in SOM and occasionally in invertebrates. PLFAs with

305 cyclopropyl rings and branched PLFAs that are typical for bacteria (O'Leary and Wilkinson

306 1988, Zelles 1999) had a substantial concentration in SOM, but were found in low

307 concentrations in the invertebrates. The $\delta^{13} \mathrm{C}$ values of these PLFAs varied between -38.5 and

$308-29.9 \%$. The monounsaturated PLFA 18:1 $107 \mathrm{c}$, typical for bacteria (Wilkinson 1988) and a

309 major PLFA in MOB (Bodelier et al. 2009), but also found in low abundance in various

310 groups of algae (Dijkman and Kromkamp 2006), was the most abundant PLFA in SOM and

311 present in all invertebrates and had $\delta^{13} \mathrm{C}$ values between -35.9 and $-29.8 \%$. The total relative

312 concentration of the above mentioned PLFAs typical for bacteria was $57.1 \%$ in SOM, $11.4 \%$

313 in zooplankton, and between $2.3 \%$ and $10.4 \%$ in the insect species.

314 The total relative concentration of polyunsaturated PLFAs (PUFAs) was $4.5 \%$ in SOM

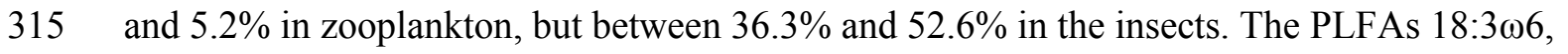

$31620: 4 \omega$ ?, and 20:5 103 were found in considerable amounts in all insects analysed here. The

317 PLFA 18:2 $\omega 6 \mathrm{c}, 9 \mathrm{c}$ was present in high concentration only in the predators Notonecta lutea,

318 Ilybius aenescens and Ilybius guttiger and (almost) absent in the other invertebrates and SOM.

319 The PLFA 18:3 06 is reported from algae (Chrysophyceae) and Cyanobacteria (Taipale et al. 
2009 and references therein) and fungi (Desvilettes et al. 1997). The PLFA 20:406 is found in

321 minor amounts in some Bacillariophyceae (diatoms), but in higher abundance in Rhodophyta

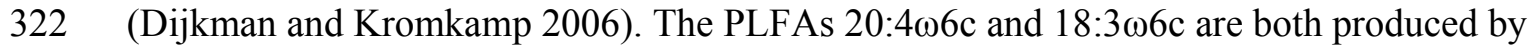

323 Protozoans grazing on MOB in wet soils (Murase et al. 2011). The PLFA 20:503 is typical

324 for various groups of algae, including diatoms and Cryptophyta (Dijkman and Kromkamp

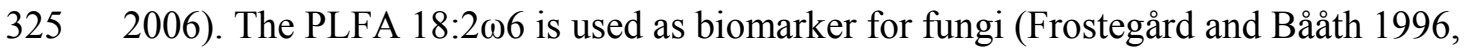

326 Desvilettes et al. 1997), for plant detritus in a freshwater system (Jaschinski et al. 2011) and

327 also present in considerable amounts in algae species of the Chlorophyta group (Dijkman and

328 Kromkamp 2006) and in Cyanobacteria (Caramujo et al. 2008).

PUFAs had the most depleted $\delta^{13} \mathrm{C}$ values among all PLFAs found. The PUFA 20:4

was the most depleted PLFA in SOM and zooplankton with $\delta^{13} \mathrm{C}$ values of $-45.5 \%$ and -

47.1\%, respectively, but less depleted in the insects, with $\delta^{13} \mathrm{C}$ values between -40.3 and -

33.2\%. In contrast to the PLFA 20:4, the PLFA 20:5 13 was more enriched in ${ }^{13} \mathrm{C}$ in SOM

than in the invertebrates. In most insects the PUFA 18:3 $\omega 6$ was the most depleted PLFA with

$334 \delta^{13} \mathrm{C}$ values between -42.3 and $-37.2 \%$. This PUFA was not detected in zooplankton and had

335 a low concentration in SOM. Therefore no reliable $\delta^{13} \mathrm{C}$ value could be obtained for 18:3 $\omega 6$ in

336 SOM.

337 Among the monounsaturated PLFAs (MUFAs), 18:1 $19 \mathrm{c}$ had the highest relative

338 concentration in the insect species (between $17.3 \%$ and $24.6 \%$ of the total amount of PLFAs).

339 In seston this PLFA is used as an indication for the phytoplankton group Chlorophyceae, in

340 particular Chlamydomonas sp. (Taipale et al. 2009), but occurs in other algae (Dijkman and

341 Kromkamp 2006) and Cyanobacteria (Caramujo et al. 2008) as well. The high relative

342 concentration of $18: 1 \omega 9 \mathrm{c}$ in the insects indicates the ingestion of algae by these insects or by

343 their prey. However, 18:109 is also a major PLFA of methanotrophs in wet peat soils (Chen

344 et al. 2008). In zooplankton the relative concentration of $18: 1 \omega 9 \mathrm{c}$ was with $10.6 \%$ lower than 
345 in the insects, but also the highest among the MUFAs, followed by $16: 1 \omega 7 \mathrm{c}(10.0 \%)$ and

$34618: 1 \omega 7 \mathrm{c}(7.2 \%)$. The PLFA $16: 1 \omega 7 \mathrm{c}$ is a major PLFA in methanotrophic bacteria, but also in

347 green sulphur bacteria (Taipale et al. 2009 and references therein), nitrifiers (De Bie et al.

348 2002), and diatoms (Dijkman and Kromkamp 2006).

349 The total relative concentration of saturated PLFAs was between $16.3 \%$ and $30.5 \%$ in

350 SOM and insects, but $60.6 \%$ in zooplankton, with $41.4 \%$ consisting of the PLFA 16:0. This

351 PLFA is also abundant in several groups of algae and bacteria (Taipale et al. 2009 and

352 references therein).

353 
Stable isotopic signatures and the role of periphyton and other potential food sources

The stable isotopic signatures of the aquatic invertebrates and the living and dead

tissue of primary producers in the raised bog pools showed the presence of multiple trophic

levels (Fig. 2) and a differential use of basal food sources by the invertebrates, not only

between species, but also among individuals, as well as different size classes of the same taxa

(Table 2). The dominant primary producers in these pools (Sphagnum mosses and vascular

362 plants) and their dead sedimented organic matter (SOM) can potentially sustain the less

363 depleted half of the invertebrate food web with $\delta^{13} \mathrm{C}$ values $>-28 \%$. The $\delta^{13} \mathrm{C}$ values of

364 dissolved organic substances (DOC) and invertebrates walking and flying around the bog

365 pools were in the same range. Periphyton, predominantly consisting of algae, but likely

366 containing different kinds of microbes as well, is the only potential food source found

367 sufficiently depleted in ${ }^{13} \mathrm{C}$ to sustain at least half the invertebrate food web more depleted in

$368{ }^{13} \mathrm{C}$. The $\delta^{13} \mathrm{C}$ values of periphyton varied considerably between the pools. In pool N1 it had a

$369 \delta^{13} \mathrm{C}$ value of $-27.4 \%$. Possibly, periphyton, or periphyton components, with a $\delta^{13} \mathrm{C}$ value $<-$

$37030 \%$ were also present in N1, like in N2 and N3. In addition, the $\delta^{13} \mathrm{C}$ values of

371 phytoplankton can be lower than -30\%o (Taipale et al. 2007). The variation in $\delta^{13} \mathrm{C}$ values of

372 the different samples of periphyton and larger algae collected in this study (between -34.7\%o

373 and -19.4\%; Table 2) and the variation in $\delta^{13} \mathrm{C}$ values of algae during the year and between

374 algae species found in other studies (e.g., Bontes et al. 2006) is high. Sampling of periphyton,

375 as well as phytoplankton, in the bog pools at different moments in the same year as the

376 invertebrates would have given more detailed information about the variation in the $\delta^{13} \mathrm{C}$

377 values of these potential food sources. It is likely that these values varied during the year and

378 that algae in periphyton and possibly also phytoplankton could be the basal food source 
sustaining the more depleted half of the invertebrate food web in all three bog pools sampled

380 here.

The stable isotopic signatures of the invertebrates and potential basal food sources

382 alone do not resolve the importance of living or dead material of Sphagnum mosses and

383 vascular plants, or particulate and dissolved organic matter originating from the peat in which

384 the pools are embedded, as basal food source for the invertebrates with $\delta^{13} \mathrm{C}$ values $>-28 \%$.

385 The range in $\delta^{13} \mathrm{C}$ values of the algae samples collected here (periphyton and larger algae)

386 implies that the whole invertebrate community could be sustained only by different species of

387 algae. Alternatively, the carbon sources for the invertebrates could consist of a combination of

388 algae, living or dead organic material from macrophytes, dissolved organic carbon

389 compounds and bacteria and fungi living in or on the various organic substrates.

\section{Biomarker PLFAs and pathways in the food web}

392 The variation in the PLFA composition (Table 4) and in the $\delta^{13} \mathrm{C}$ values of PLFAs

393 (Table 5) of the invertebrates indicates that they used different basal food sources. They

394 assimilated fatty acids that are specific for MOB, for other bacteria, as well as

395 polyunsaturated fatty acids (PUFAs) that are derived from algae, and maybe macrophytes,

396 either or not via fungi. These PLFA data confirm the importance of algae (periphyton and

397 possibly phytoplankton) inferred from the stable isotope data. The elucidation of the relative

398 importance of these basal food sources to the invertebrate food web of bog pools is however

399 somewhat constrained because many of the recorded PLFAs cannot unambiguously be

400 attributed to either macrophytes, algae, or methanotrophic or other bacteria. Furthermore,

401 eukaryotes other than algae or macrophytes might synthesize PUFAs that are used as

402 biomarkers for algae. 


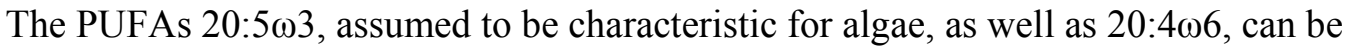

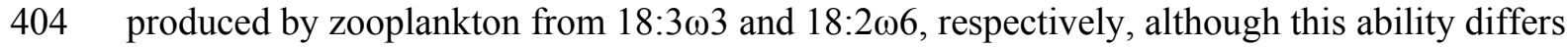

405 between groups (Caramujo et al. 2008 and references therein). According to Arts (1999) most

406 species of freshwater zooplankton cannot synthesize or elongate PUFAs with 18 or $20 \mathrm{C}$ -

407 atoms and must obtain them from their diet. This inability is also found for omnivorous

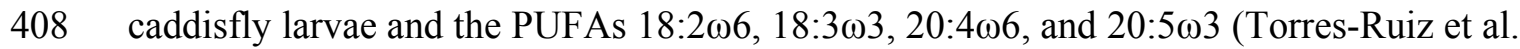

409 2010). This finding may therefore be extended for the invertebrate species studied here.

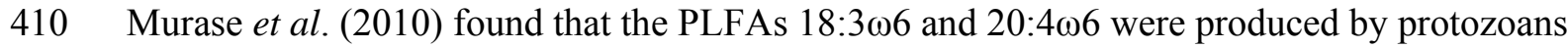

411 grazing on MOB. It is unknown if this pathway is important in bog pools. However, it is

412 unlikely to be the only pathway conveying these PLFAs to the insects, as the amounts of

$41318: 3 \omega 6,20: 4 \omega ?, 20: 5 \omega 3$, and their possible $\omega 6$ and $\omega 3$ precursors in SOM and zooplankton

414 are small compared to the high amounts of these PUFAs in the insects (Table 5), although

415 preferential assimilation of PUFAs by the insects might result in a higher relative amount of

416 PUFAs in the insects than in their food. Moreover, the abundance of green algae and the

417 presence of some pieces of Sphagnum mosses and other macrophytes in the guts of several

418 insects in the pools studied here (Odonata nymphs and larvae of Chironomidae and

419 Trichoptera; personal observations) support the conclusion that algae are indeed an important

420 basal food source in the bog pool food web, next to bacteria and possibly macrophytes,

421 especially for the insects that all showed a high concentration of PUFAs (Fig. 3).

422 The amount of 20:5 23 , characteristic for diatoms and also present in some other

423 groups of algae, but absent in bacteria, might help to roughly estimate the relative amount of

424 PLFAs originating from either bacteria or algae in SOM and invertebrates, when a more or

425 less constant ratio between 20:5 03 and the other PLFAs in the algal community is assumed.

426 The relative amount of the PLFA 20:503 in zooplankton was six times higher than in SOM,

427 and in insects it was fourteen to thirty-seven times higher than in SOM (Table 5). Thus, most 
of the PLFA content in SOM was present in the bacterial community, and possibly partly in

429 protozoa like flagellates and ciliates that ingested them. In the invertebrates much larger parts

430 of the PLFA content originated from algae, but the insects seem to rely more on algae than 431 pelagic zooplankton does (Fig. 3).

432 In the zooplankton the total relative amount of PLFAs characteristic for bacteria given 433 in Table $5(11.4 \%)$ was much lower than in SOM (57.1\%) and closer to the range found in the 434 insects (2.3-10.4\%). However, PLFA composition was different, with a high amount of the 435 PLFAs 14:0, 16:0 and 16:1 $17 \mathrm{c}$ in the zooplankton relative to both SOM and insects.

436 Remarkably, these were the main PLFAs in which labelled methane was incorporated in 437 forest soil samples (Knief et al. 2003). The relative amount of the PLFA 16:1 $\omega 5$ t, typical for 438 MOB I, was also higher in the zooplankton than in SOM and insects. Taken together, this 439 suggests that the zooplankton assimilated much more fatty acids originating from MOB 440 (ingested directly as part of ingested seston or via protozoans) and two to six times less from 441 algae than the insects did, directly or via their prey (Fig. 3). Additionally, differences between 442 SOM and zooplankton in their PLFA composition and in the $\delta^{13} \mathrm{C}$ values of PLFAs can result 443 from preferential assimilation of PLFAs by zooplankton. Preferential ingestion of bacteria by 444 the protozoa upon which the zooplankton preys is another possibility. For example, Murase 445 and colleagues (2010) found protozoans preferring MOB I above MOB II. Finally, the 446 composition of the bacteria community may differ between the seston ingested by 447 zooplankton (collected in open water) and SOM (collected at the bottom of the pool), with a 448 higher relative abundance of MOB in the seston. Elucidation of the various pathways in 449 which this could come about require further investigations, but the available data indicate that 450 MOB are a significant food source for pelagic zooplankton in bog pools (Fig. 3), something 451 which was also found in lake pelagic food webs (Bastviken et al. 2003, Taipale et al. 2007). 
453 dominated by bacteria. In a wide range of bacterial dominated sediments the sum of the

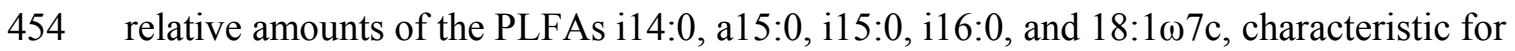
455 bacteria, is $28 \pm 4 \%$ (Middelburg et al. 2000). This sum was much higher in the SOM of the 456 bog pools studied here (41.3\%), due to the high abundance of $18: 1 \omega 7 \mathrm{c}(31 \%)$. The PLFA $457 \quad 18: 1 \omega 7 \mathrm{c}$ is likely to be the prevailing lipid in methanotrophs in Sphagnum moss (Bodelier et 458 al. 2009, Van Winden et al. 2010). Using the relative amount of the MOB specific PLFAs $459 \quad 16: 1 \omega 8 \mathrm{c}$ and $18: 1 \omega 8 \mathrm{c}$ in SOM and the fairly constant ratio between these specific PLFAs and 460 non-specific PLFAs found in MOB strains (Bodelier et al. 2009), we may assume the MOB to 461 make up about $10 \%$ of the bacterial population in the SOM.

462

A pathway of methane to invertebrates via algae?

As methane and MOB are depleted in ${ }^{13} \mathrm{C}$, the $\delta^{13} \mathrm{C}$ values of invertebrates

assimilating methane-derived carbon are similarly depleted (Taipale et al. 2007 and 2009).

466 The low $\delta^{13} \mathrm{C}$ values of the zooplankton samples compared to most insects, including all

467 insects of low trophic level (Table 2), indeed corresponds to the larger reliance of zooplankton on MOB inferred from the PLFA data. However, overall, the PUFAs characteristic for algae or other plants $(18: 3 \omega 6,20: 4 \omega ?, 20: 5 \omega 3)$ were more depleted than the PLFAs typical for bacteria, including the PLFAs typical for MOB. For some of these PUFAs 471 this could be explained by the possibility that they can also be synthesized by protozoans (c.f. 472 Murase et al. 2010) or zooplankton (c.f. Caramujo et al. 2008). The PLFA 20:4 $\omega$ ? was much 473 more depleted in ${ }^{13} \mathrm{C}$ in the zooplankton than in the insects, indicating a difference in carbon 474 pathways. As methane is known to be depleted in ${ }^{13} \mathrm{C}$, this would suggest that the zooplankton 475 synthesized this PLFA from precursor fatty acids (c.f. Caramujo et al. 2008) ingested via 
MOB, or that they ingested protozoa that synthesized this PLFA (c.f. Murase et al. 2010),

477 whereas the insects might get the PLFA 20:4 $\omega$ ? via algae and herbivorous prey.

It is, however, remarkable that in zooplankton the $\delta^{13} \mathrm{C}$ values of the PLFAs $16: 1 \omega 7 \mathrm{c}$,

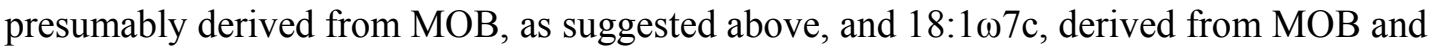
other bacteria, were also generally less depleted than in the insects (Table 6). As methane is depleted in ${ }^{13} \mathrm{C}$, the $\delta^{13} \mathrm{C}$ values of the PLFAs in MOB are expected to be lower than those in 482 algae, assuming the latter use $\mathrm{CO}_{2}$ for photosynthesis. However, Raghoebarsing et al. (2005) 483 showed that submerged Sphagnum mosses can use $\mathrm{CH}_{4}$ as carbon source, converted to $\mathrm{CO}_{2}$ 484 via endosymbiontic MOB. Could also the algae in bog pools obtain methane-derived $\mathrm{CO}_{2}$ via 485 MOB living as endosymbionts or as a constituent of the periphyton (or biofilm), explaining 486 the relatively depleted $\delta^{13} \mathrm{C}$ values of algae-derived PUFAs in the insects? Labelling studies 487 with ${ }^{13} \mathrm{C}$-bicarbonate or ${ }^{13} \mathrm{CH}_{4}$ (Raghoebarsing et al. 2005, Deines et al. 2007, Pace et al. 488 2007) are required to verify the existence of such intriguing pathways from both MOB and 489 algae in the food web of bog pools.

490

Combining the outcomes of stable isotopes and PLFA analyses

The variation in the stable isotopic signatures (Table 2), the PLFA composition (Table 493 5), and the $\delta^{13} \mathrm{C}$ values of PLFAs (Table 6) indicated that the invertebrates in bog pools use 494 different basal food sources. The $\delta^{13} \mathrm{C}$ values of different potential basal food sources and 495 invertebrates indicated that algae (in periphyton and possibly phytoplankton) sustain at least 496 half the invertebrate food web. The PLFA composition showed that algae, MOB and other 497 bacteria are ingested by the invertebrates, directly or via their prey. Pelagic zooplankton 498 seems to rely more on bacteria, whereas for insects algae are more important. This variation in 499 relative importance of basal food sources is indicated in the schematic representation of the 500 food web (Fig. 3) with variation in the thickness of the black arrows. A considerable part of 
501 the bacterial biomass conveyed to higher trophic levels in the bog pools likely originates from

502 MOB. The results suggest that algae in bog pools use methane derived carbon, possibly via

503 MOB (indicated with the grey curved arrows in Fig. 3). Invertebrates grazing on periphyton

504 likely ingest the MOB associated with the periphyton. Thus, depleted $\delta^{13} \mathrm{C}$ values of whole

505 organisms, or PLFAs, do not necessarily implicate a direct pathway between MOB and these

506 organisms. Instead, algae could be an intermediate, constituting a major food source for

507 aquatic invertebrates.

508 
511 This paper is dedicated to the memory of Hans Esselink (deceased 30 August 2008)

512 who initiated this research project and stimulated several studies on ecosystem functioning

513 and biodiversity conservation. Fons Smolders and Jan Roelofs are acknowledged for their

514 support and advise during this study. Nigula Nature Reserve Administration (Estonia) is

515 acknowledged for giving permission to collect samples in their reserve and for providing the

516 facilities. Juhan Javoiš, Jan Kuper, Theo Peeters, Eva Remke, Michel Smits, Ankie de Vries-

517 Brock, Mara van der Weijden, Maria Judith Sanabria and Yan Zhuge assisted with the field

518 and laboratory work. Jelle Eygensteyn performed most stable isotope measurements. Peter

519 van Breugel, Marco Houtekamer and Steven Bouillon took care of the analyses of the DOC

520 samples. Lea Tuvikene assisted by freeze drying of the invertebrates and Kees Hordijk

521 performed the analyses of the PLFAs. This research project was part of the national research

522 programme 'Survival Plan for Woodland and Nature', funded by the Dutch Ministry of

523 Agriculture, Nature and Food Quality.

524 


\section{Literature Cited}

526

527 Aerts, R., J. T. A. Verhoeven, And D. F. Whigham. 1999. Plant-mediated controls on 528 nutrient cycling in temperate fens and bogs. Ecology 80:2170-2181.

ARTS, M.T. 1999. Lipids in freshwater zooplankton: selected ecological and physiological

530 aspects. Pp. 71-87 in M. T. Arts, and B. C. Wainman (editors). Lipids in freshwater

531 ecosystems. Springer, New York.

532 Bastviken, B., J. EjLertsson, I. Sundh, And L. Tranvik. 2003. Methane as a source of

533 carbon and energy for lake pelagic food webs. Ecology 84:969-981.

534 BELYEA, L. R. 1996. Separating the effects of litter quality and microenvironment on

535 decomposition rates in a patterned peatland. Oikos 77:529-539.

536 BelyeA, L. R. AND J. LANCASTER. 1996. Inferring Landscape Dynamics of Bog Pools from

537 Scaling Relationships and Spatial Patterns. Journal of Ecology 90:22-234.

538 Bodelier, P. L. E., M. -J. BÄr Gillisen, K. HordiJK, J. S. Sinninghe Damsté, W. I. C.

539 Rijpstra, J. A. J. GeEneVAsen, And P. F. Dunfield. 2009. A reanalysis of phospholipid

540 fatty acids as ecological biomarkers for methanotrophic bacteria. ISME Journal 3:606-617.

541 Bontes, B. M., R. Pel, B. W. Ibelings, H. T. S. Boschker, J. J. Middelburg, And E. van

542 DONK. 2006. The effects of biomanipulation on the biogeochemistry, carbon isotopic

543 composition and pelagic food web relations of a shallow lake. Biogeosciences 3:69-83.

544 Boschker, H.T. S., W. De Graaf, M. Koster, L. A. Meyer-Reil, T. E. Cappenberg. 2001.

545 Bacterial populations and processes involved in acetate and propionate consumption in

546 anoxic brackish sediment. FEMS Microbiology Ecology 35:97-103.

547 BoschKer, H. T. S. AND J. J. MidDELBURG. 2002. Stable isotopes and biomarkers in microbial 548 ecology. FEMS Microbiology Ecology 40:85-95. 
Boschker, H. T. S., S. C. Nold, P. Wellsbury, D. Bos, W. De GraAf, R. Pel, R. J. Parkes,

550 AND T. E. CAPPENBERG. 1998. Direct linking of microbial populations to specific

551 biogeochemical processes by ${ }^{13} \mathrm{C}$-labelling of biomarkers. Nature 392:801-805.

552 Boschker, H. T. S., T. C. W. MoerdiJk-Poortvliet, P. van Breugel, M. Houtekamer,

553 AND J. J. MidDELBURG. 2008. A versatile method for stable carbon isotope analysis of

554 carbohydrates by high-performance liquid chromatography/isotope ratio mass spectrometry.

555 Rapid Communications in Mass Spectrometry 22:3902-3908.

556 Caramujo, M. -J., H. T. S. BoschKer, AND W. AdmiraAL. 2008. Fatty acid profiles of algae

557 mark the development and composition of harpacticoid copepods. Freshwater Biology

$558 \quad 53: 77-90$.

559 Chen Y., M. G. Dumont, M. P. McNamara, P. M. Chamberlain, L. Bodrossy, N.

560 Stralis-PaVese, AND J. C. MURRELl. 2008. Diversity of the active methanotrophic

561 community in acidic peatlands as assessed by mRNA and SIP-PLFA analyses.

562 Environmental Microbiology 10:446-459.

563 De Bie, M. J. M., M. Starink, H. T. S. Boschker, J. J. Peene, And H. J. LaAnbroek. 2002.

564 Nitrification in the Schelde estuary:methodological aspects and factors influencing its

565 activity. FEMS Microbiology Ecology 42:99-107.

566 DeINES, P., P. L. E. BodELIER, AND G. ELLER. 2007. Methane-derived carbon flows through

567 methane-oxidizing bacteria to higher trophic levels in aquatic systems. Environmental

568 Microbiology 9:1126-1134.

569 DENIRO, M. J., AND S. EPSTEIN. 1978. Influence of diet on the distribution of carbon isotopes

570 in animals. Geochimica and Cosmochimica Acta 42:495-506.

571 Desrochers, A., And G. A. Van Duinen. 2006. Peatland Fauna. Pp. 67-100 in R. K. Wieder, 572 and D. H. Vitt (editors). Boreal Peatland Ecosystems. Ecological Studies, Vol. 18. Springer$573 \quad$ Verlag, New York. 
574 Desvilettes, CH., G. Bourdier, CH. Amblard, AND B. Barth. 1997. Use of fatty acids for

575 the assessment of zooplankton grazing on bacteria, protozoans and microalgae. Freshwater

576 Biology 38:629-637.

577 DiJKman, N. A., AND J. C. KROMKAMP. 2006. Phospholipid-derived fatty acids as

578 chemotaxonomic markers for phytoplankton:application for inferring phytoplankton

579 composition. Marine Ecology Progress Series 324:113-125.

580 FROSTEGÅRD A., AND E. BÅÂTH. 1996. The use of phospholipid fatty acid analysis to estimate

581 bacterial and fungal biomass in soil. Biology and Fertility of Soils 22:59-65.

582 GREY, J., R. I. JONES, AND D. SLEEP. 2000. Stable isotope analysis of the origins of

583 zooplankton carbon in lakes of differing trophic state. Oecologia 123:232-240.

584 Guckert, J. B., C. P. Antworth, P. D. Nichols, And D. C White. 1985. Phospholipid, ester-

585 linked fatty-acid profiles as reproducible assays for changes in prokaryotic community

586 structure of estuarine sediments. FEMS Microbiology Ecology 31:147-158.

587 HigleR, B. 2005. De Nederlandse kokerjufferlarven. Uitgeverij KNNV, Utrecht.

588 JASCHINSKI, S., D. BREPOHL, AND U. SOMMER. 2011. The trophic importance of epiphytic

589 algae in a freshwater macrophyte system (Potamogeton perfoliatus L.):stable isotope and

$590 \quad$ fatty acid analyses. Aquatic Sciences 73:91-101.

591 JONES, R. I. 1992. The influence of humic substances on lacustrine planktonic food chains.

592 Hydrobiologia 229:73-91.

593 Jones, R. I., C. E. CARter, A. Kelly, S. WARD, D. J. Kelly, And J. Grey. 2008. Widespread

594 contribution of methane-cycle bacteria to the diets of lake profundal chironomid larvae.

$595 \quad$ Ecology 89:857-864.

596 JONES, R. I., AND J. GREY. 2011. Biogenic methane in freshwater food webs. Freshwater

597 Biology 56:213-229. 
Karlsson, J., P. Byström, J. Ask, P. Ask, L. Persson, And M. JANSSON. 2009. Light

599 limitation of nutrient-poor lake ecosystems. Nature 460:506-509.

600 Kato, Y., M. Hori, N. OKUDA, I. TAYASU, AND Y. TAKEMON. 2010. Spatial heterogeneity of

601 trophic pathways in the invertebrate community of a temperate bog. Freshwater Biology

$602 \quad 55: 450-462$.

603 KharlamenKo, V. I., S. I. KiYAShKO, A. B. IMBS, AND D. I. VyShKVARTZEV. 2001.

604 Identification of food sources of invertebrates from the seagrass Zostera marina community

605 using carbon and sulfur stable isotope ratio and fatty acid analyses. Marine Ecology-

606 Progress Series 220:103-117.

607 KNIEF, C., A. LIPSKI, AND P. F. DUNFIELD. 2003. Diversity and activity of methanotrophic

608 bacteria in different upland soils. Applied Environmental Microbiology 69:6703-6714.

609 Kroppenstedt, R. M. 1992. The genus Nocardiopsis. Pp. 1139-1156 in A. Balows, H. G.

610 Trüper, M. Dworkin, W. Harder, and K. H. Schleifer (editors). The prokaryotes 2. Springer, 611 Berlin Heidelberg New York.

612 McCutchan, J. H., W. M. Lewis, C. Kendall, And C. C. McGrath. 2003. Variation in 613 trophic shift for stable isotope ratios of carbon, nitrogen, and sulfur. Oikos 102:378-390.

614 Middelburg, J. J., C. Barranguet, H. T. S. Boschker, P. M. J. Herman, T. Moens, and C.

615 H. R. HEIP. 2000. The fate of intertidal microphytobenthos carbon:An in situ ${ }^{13}$ C-labeling

616 study. Limnology and Oceanography 45:1224-1234.

617 Minagawa, M., AND E. WADA. 1984. Stepwise enrichment of N-15 along food-chains -

618 further evidence and the relation between delta-N-15 and animal age. Geochimica et 619 Cosmochimica Acta 48:1135-1140.

620 MOHANTy, S. R., P. L. E. BODELIER, V. Floris, AND R. CONRAD. 2006. Differential effects of 621 nitrogenous fertilizers on methane-consuming microbes in rice field and forest soils.

622 Applied and Environmental Microbiology 72:1346-1354. 
623 Moller Pillot, H. K. M. 2009. Chironomidae larvae:Biology and ecology of the

624 Chironomini. KNNV Publishing, Zeist, The Netherlands.

625 Murase, J., K. HordiJK, I. TAYASU, AND P. L. A. Bodelier. 2010. Strain-specific

626 incorporation of methanotrophic biomass into eukaryotic grazers in a rice field soil revealed

627 by PLFA-SIP. FEMS Microbiology Ecology 75:284-290.

628 Nichols, P. D., G. A. Smith, C. P. Antworth, R. S. Hanson, And D. C. White. 1985.

629 Phospholipid and lipopolysaccharide normal and hydroxy fatty-acids as potential signatures

630 for methane-oxidizing bacteria. FEMS Microbiology Ecology 31:327-335.

631 Nilsson, A. 1996. Aquatic insects of North Europe. Vol. 1. Apollo Books APs., Stenstrup.

632 NiLsson, A. 1997. Aquatic insects of North Europe. Vol. 2. Apollo Books APs., Stenstrup.

633 O’LeARY, W. M., AND S. G. WILKInSON. 1988. Gram-positive bacteria. Pp 117-202 in

634 Ratledge, C., and S. G Wilkinson (editors). Microbial lipids, vol 1. Academic Press, 635 London.

636 Pace, M. L., S. R. Carpenter, J. J. Cole, J. Coloso, J. F. Kitchell, J. R. Hodgson, J. J.

637 Middelburg, N. D. Preston, C. Solomon, And B. Weidel. 2007. Does terrestrial carbon

638 subsidize plankton in a clear-water lake. Limnology and Oceanography 52:2177-2189.

639 Perga, M., M. Kainz, B. Matthews And A. MaZumder. 2006. Carbon pathways to

640 zooplankton:insights from the combined use of stable isotope and fatty acid biomarkers.

$641 \quad$ Freshwater Biology 51:2041-2051.

642 PhiLliPS, D. L., AND J. W. GREGG. 2003. Source partitioning using stable isotopes:coping with 643 too many sources. Oecologia 136:261-269.

644 Post, D. M. 2002. Using stable isotopes to estimate trophic position:Models, methods, and 645 assumptions. Ecology 83:703-718.

646 Raghoebarsing, A. A., A. J. P. Smolders, M. C. Schmid, W. I. C. RiJPSTRA, M. Wolters-

647 Arts, J. Derksen, M. S. M. Jetten, S. Schouten, J. S. Sinninghe Damsté, L. P. M. 

symbionts provide carbon for photosynthesis in peat bogs. Nature 436:1153-1156.

Rydin, H., AND J. K. JEGLUM. 2006. The biology of peatlands. Oxford University Press.

Smolders, A.J.P., H. B. M. Tomassen, L. P. M. Lamers, B. P. Lomans, And J. G. M.

652 ROELOFS. 2002. Peat bog restoration by floating raft formation: the effects of groundwater 653 and peat quality. Journal of Applied Ecology 39:391-401.

654 TAiPele, S., P. KANKAALA, AND R. I. JONES. 2007. Contributions of different organic carbon 655 sources to Daphnia in the pelagic foodweb of a small polyhumic lake: Results from 656 mesocosm DI ${ }^{13} \mathrm{C}$-additions. Ecosystems 10:757-772.

657 TAiPAle, S., P. KANKAAla, H. HÄMÄLÄINEN, AND R. I. JONES. 2009. Seasonal shifts in the 658 diet of lake zooplankton revealed by phospholipid fatty acid analysis. Freshwater Biology $659 \quad 54: 90-104$.

660 Torres-Ruiz, M., J. D. Wehr, And A. A. Perrone. 2010. Are net-spinning caddisflies what 661 they eat? An investigation using controlled diets and fatty acids. Journal of the North 662 American Benthological Society 29:803-813.

663 TRANVIK, L. 1988. Availability of dissolved organic carbon for planktonic bacteria in 664 oligotrophic lakes of differing humic content. Microbial Ecology 16:311-322.

665 Trimmer, M., A. G. Hildrew, M. C. Jackson, J. L. Pretty, and J. Grey. 2009. Evidence for 666 the role of methane-derived carbon in a free-flowing, lowland river food web. Limnology 667 and Oceanography 54:1541-1547.

668 VallenduuK, H. J., AND H. K. M. Moller Pillot. 2007. Chironomidae larvae:General 669 ecology and Tanypodinae. KNNV Publishing, Zeist, The Netherlands.

670 Van den Meersche, K., P. Van Rijswijk, K. Soetaert, and J .J. Middelburg. 2009.

671 Autochthonous and allochthonous contributions to mesozooplankton diet in a tidal river and 
672 estuary: Integrating carbon isotope and fatty acid constraints. Limnology and Oceanography $673 \quad 54: 62-74$.

674 Van Duinen, G. A., A. M. T. Brock, J. T. Kuper, R. S. E. W. Leuven, T. M. J. Peeters, J. G. 675 M. Roelofs, G. VAn Der Velde, W. C. E. P. Verberk, ANd H. Esselink. 2003. Do 676 restoration measures rehabilitate fauna diversity in raised bogs? A comparative study on 677 aquatic macroinvertebrates. Wetlands Ecology and Management 11:447-459.

678 Van Duinen, G. A., K. Vermonden, A. M. T. Brock, R. S. E. W. Leuven, A. J. P.

679 Smolders, G. VAn der Velde, W. C. E. P. Verberk, And H. Esselink. 2006a. Basal food 680 sources for the invertebrate food web in nutrient poor and nutrient enriched raised bog 681 pools. Proceeding of the Netherlands Entomological Society 17:37-44.

682 Van Duinen, G. A., T. Timm, A. J. P. Smolders, A. M. T. Brock, W. C. E. P Verberk, ANd 683 H. ESSELINK. 2006b. Differential response of aquatic oligochaete species to increased 684 nutrient availability - a comparative study between Estonian and Dutch raised bogs. 685 Hydrobiologia 564:143-155.

686 Van Winden, J. F., N. Kip, G. -J. Reichart, M. S. M. Jetten, H. J. M. Op den CAMP, J. S. 687 SINNINGHE DAMSTÉ. 2010. Lipids of symbiotic methane-oxidizing bacteria in peat moss 688 studied using stable carbon isotopic labeling. Organic Geochemistry 41:1040-1044.

689 Verberk, W. C. E. P., G. A. van Duinen, A. M. T. Brock, R. S. E. W. Leuven, H. Siepel, P. 690 F. M. VERDONSCHOt, G. VAN DER VELDE, AND H. ESSELINK. 2006. Importance of landscape 691 heterogeneity for the conservation of aquatic macroinvertebrate diversity in bog landscapes. 692 Journal for Nature Conservation 14:78-90.

693 WiLKInSON, S. G. 1988. Gram-negative bacteria. Pp. 299-488 in C. Ratledge, and S.G.

694 Wilkinson (editors). Microbial Lipids, Vol. 1. Academic Press, London. 
695 ZELLES, L. 1999. Fatty acid patterns of phospholipids and lipopolysaccharides in the

696 characterisation of microbial communities in soil: a review. Biology and Fertility of Soils

$697 \quad 29: 111-129$.

698

699 
Table 1. Average ( \pm standard deviation) quality data of surface water, sediment pore water and sedimented organic matter at the sampling sites. $\mathrm{N}=2$ sampling periods.

702

703

704 Table 2. Values (\%o) of $\delta^{15} \mathrm{~N}$ and $\delta^{13} \mathrm{C}$ of sedimented and dissolved organic matter, plants and 705 invertebrates of the three bog pools N1, N2 and N3. Invertebrates are arranged according to trophic group indicated in column $\mathrm{T}(\mathrm{c}=$ carnivore, $\mathrm{d}=$ detritivore, $\mathrm{h}=$ herbivore, $\mathrm{hd}=$ herbidetritivore, $\mathrm{o}=$ omnivore) and subsequently to taxonomical group indicated in column 'Tax.' (Odo=Odonata, Het=Heteroptera, Col=Coleoptera, Meg=Megaloptera， Dip=Diptera, Tri=Trichoptera, Ara=Aranaea, Cru=Crustacea, Eph=Ephemeroptera). In column \# the number 1 indicates that specimens of the species or higher taxon were analysed individually,

711 otherwise individuals were pooled per species or higher taxon.

714 Table 3. Values (\%) of $\delta^{15} \mathrm{~N}$ and $\delta^{13} \mathrm{C}$ of invertebrates (imagines, unless otherwise indicated) 715 walking and flying around the bog pools. The taxa are arranged from low to high $\delta^{13} \mathrm{C}$.

Table 4. Means and 1 and 99 percentiles of the feasible contribution of potential basal carbon sources to the different trophic groups of invertebrates. The classification of invertebrate species in the trophic groups is given in Table 2. (SOM) and aquatic invertebrates. 
727 Table $6.813 \mathrm{C}(\%)$ of PLFAs in sedimented organic matter (SOM) and aquatic invertebrates. 728

729

730 Figure 1. Geographical location of the three raised bog pools studied in Nigula Nature

731 Reserve, Southwest Estonia.

732

733

734 Figure 2. Average values $\pm \mathrm{SE}(\%)$ of $\delta^{15} \mathrm{~N}$ and $\delta^{13} \mathrm{C}$ of different groups of primary 735 producers, sedimented organic matter (SOM), and different trophic groups of invertebrate

736 species in the bog pools N1, N2, and N3. The vertical lines indicates the average $\delta^{13} \mathrm{C}( \pm \mathrm{SE})$

737 of dissolved organic matter (DOC) of the three bog pools. The classification of invertebrates 738 in the different trophic groups is given in Table 2.

739

740

741 Figure 3. Schematic representation of the food web in raised bog pools. The thickness of the 742 black arrows indicate the relative importance of that relation to the invertebrate group, as 743 derived form the results described in this paper. The grey curved arrows indicate the possible 744 role of methane oxidising bacteria $(\mathrm{MOB})$ in the carbon supply to the primary producers. 


\begin{tabular}{|c|c|c|c|}
\hline Site & Nigula 1 & Nigula 2 & Nigula 3 \\
\hline \multicolumn{4}{|l|}{ Surface water } \\
\hline $\mathrm{pH}$ & $3.9 \pm 0.1$ & $3.9 \pm 0.2$ & $4.0 \pm 0.1$ \\
\hline $\mathrm{o}-\mathrm{PO}_{4}(\mu \mathrm{mol} / \mathrm{L})$ & $0.23 \pm 0.10$ & $0.17 \pm 0.16$ & $0.28 \pm 0.01$ \\
\hline $\mathrm{NO}_{3}+\mathrm{NH}_{4}(\mu \mathrm{mol} / \mathrm{L})$ & $4.8 \pm 2.5$ & $9.3 \pm 4.0$ & $10.7 \pm 9.0$ \\
\hline $\mathrm{Ca}(\mu \mathrm{mol} / \mathrm{L})$ & $17.2 \pm 8.9$ & $23.3 \pm 12.0$ & $25.3 \pm 9.9$ \\
\hline $\mathrm{Cl}(\mu \mathrm{mol} / \mathrm{L})$ & $58.7 \pm 5.3$ & $90.5 \pm 31.3$ & $71.3 \pm 5.9$ \\
\hline Dissolved inorganic carbon (DIC) $(\mu \mathrm{mol} / \mathrm{L})$ & $22.6 \pm 31.9$ & $44.7 \pm 25.5$ & $32.6 \pm 40.2$ \\
\hline Dissolved organic carbon (DOC) $(\mu \mathrm{mol} / \mathrm{L})$ & $1654 \pm 98$ & $1925 \pm 59$ & $1671 \pm 457$ \\
\hline \multicolumn{4}{|l|}{ Sediment pore water } \\
\hline $\mathrm{pH}$ & $4.7 \pm 0.7$ & $4.6 \pm 0.6$ & $4.5 \pm 0.2$ \\
\hline $\mathrm{o}-\mathrm{PO}_{4}(\mu \mathrm{mol} / \mathrm{L})$ & $0.18 \pm 0.06$ & $0.16 \pm 0.11$ & $0.47 \pm 0.65$ \\
\hline $\mathrm{NO}_{3}+\mathrm{NH}_{4}(\mu \mathrm{mol} / \mathrm{L})$ & $2.2 \pm 2.6$ & $12.7 \pm 14.5$ & $26.6 \pm 17.6$ \\
\hline $\mathrm{Ca}(\mu \mathrm{mol} / \mathrm{L})$ & $58.2 \pm 44.5$ & $55.1 \pm 37.7$ & $51.0 \pm 26.7$ \\
\hline $\mathrm{Cl}(\mu \mathrm{mol} / \mathrm{L})$ & $55.2 \pm 8.9$ & $58.5 \pm 6.9$ & $63.0 \pm 18.3$ \\
\hline Dissolved inorganic carbon (DIC) $(\mu \mathrm{mol} / \mathrm{L})$ & $42.3 \pm 14.9$ & $38.9 \pm 14.9$ & $54.2 \pm 29.1$ \\
\hline \multicolumn{4}{|l|}{ Sedimented organic matter } \\
\hline C:P (g/g) & $1293 \pm 636$ & $1309 \pm 403$ & $652 \pm 347$ \\
\hline $\mathrm{C}: \mathrm{N}(\mathrm{g} / \mathrm{g})$ & $29.8 \pm 17.7$ & $24.7 \pm 15.1$ & $17.2 \pm 5.7$ \\
\hline $\mathrm{Ca}(\mu \mathrm{mol} / \mathrm{gDW})$ & $72.9 \pm 25.1$ & $51.3 \pm 10.0$ & $66.4 \pm 14.3$ \\
\hline
\end{tabular}




\begin{tabular}{|c|c|c|c|c|c|c|c|c|c|}
\hline \multirow[b]{2}{*}{ Species } & \multirow[b]{2}{*}{$\#$} & \multirow[b]{2}{*}{ Tax. } & \multirow[b]{2}{*}{$\mathbf{T}$} & \multicolumn{2}{|c|}{ N1 } & \multicolumn{2}{|c|}{$\mathbf{N 2}$} & \multicolumn{2}{|c|}{$\mathbf{N 3}$} \\
\hline & & & & $\delta^{15} \mathbf{N}$ & $\delta^{13} \mathrm{C}$ & $\delta^{15} \mathbf{N}$ & $\delta^{13} \mathrm{C}$ & $\delta^{15} \mathbf{N}$ & $\delta^{13} \mathrm{C}$ \\
\hline Sedimented organic matter (SOM) & & & & -2.52 & -25.97 & -3.21 & -26.36 & -2.66 & -25.41 \\
\hline Dissolved organic carbon (DOC) & & & & & -27.58 & & -27.57 & & -26.63 \\
\hline Periphyton & & & & -3.24 & -27.42 & -1.80 & -31.53 & -3.56 & -34.69 \\
\hline Branched green algae & & & & -3.40 & -25.71 & & & -0.75 & -23.33 \\
\hline Filamentous green algae & & & & -2.29 & -24.35 & -2.37 & -19.42 & -2.15 & -22.40 \\
\hline Leaf moss (submerged) & & & & -3.38 & -28.24 & -3.05 & -27.89 & -0.84 & -25.41 \\
\hline Sphagnum cuspidatum (submerged) & & & & -2.39 & -26.73 & -2.11 & -26.58 & 1.22 & -23.92 \\
\hline S. magellanicum (from lawn) & & & & -3.35 & -24.50 & -4.03 & -24.76 & -5.14 & -27.44 \\
\hline S. magellanicum (submerged) & & & & -2.48 & -24.53 & -3.60 & -24.59 & & \\
\hline Carex limosa (living plant) & & & & & & -5.72 & -27.79 & -0.87 & -27.27 \\
\hline Carex rostrata (dead leaves) & & & & & & & & -0.85 & -26.58 \\
\hline Carex rostrata (water) & & & & & & & & -0.35 & -26.75 \\
\hline Carex rostrata (roots) & & & & & & & & -3.17 & -26.69 \\
\hline Scheuchzeria palustris & & & & & & -6.06 & -25.57 & -2.65 & -26.19 \\
\hline Rhynchospora alba & & & & -3.55 & -27.40 & & & & \\
\hline Utricularia minor & & & & & & -1.18 & -22.51 & -1.41 & -21.06 \\
\hline Betula spec. fallen leaves & & & & -7.43 & -29.62 & & & & \\
\hline Zygoptera nymphs & & Odo & $\mathrm{C}$ & 2.05 & -30.41 & 1.13 & -27.46 & 1.61 & -27.39 \\
\hline Anisoptera young nymphs & & Odo & $\mathrm{C}$ & 0.44 & -25.37 & 0.41 & -25.89 & 0.48 & -25.67 \\
\hline Anisoptera last stage nymphs & & Odo & $\mathrm{C}$ & 0.88 & -27.95 & & & & \\
\hline Anax imperator nymphs last stage & & Odo & $\mathrm{c}$ & & & 2.77 & -29.62 & & \\
\hline Anax imperator young nymphs & & Odo & $\mathrm{C}$ & & & 2.24 & -28.09 & & \\
\hline Aeshna spec. nymphs & & Odo & $\mathrm{c}$ & 1.01 & -26.35 & & & 0.39 & -27.87 \\
\hline Libellula spec. nymphe 1 & 1 & Odo & $\mathrm{C}$ & 0.87 & -31.18 & & & -0.44 & -26.92 \\
\hline Libellula spec. nymphe 2 & 1 & Odo & $\mathrm{c}$ & -0.31 & -30.26 & & & 0.18 & -27.77 \\
\hline Leucorrhinia spec. nymphs & & Odo & $\mathrm{C}$ & 0.18 & -25.51 & & & & \\
\hline Libellulidae nymphs & & Odo & $\mathrm{C}$ & 0.65 & -30.12 & 0.48 & -29.32 & -0.77 & -27.77 \\
\hline Cymatia bonsdorffii & & Het & $\mathrm{c}$ & 0.77 & -30.97 & 1.47 & -32.77 & -0.38 & -30.02 \\
\hline Notonecta glauca 1 & 1 & Het & $\mathrm{C}$ & 1.22 & -28.52 & & & & \\
\hline Notonecta glauca 2 & 1 & Het & $\mathrm{c}$ & 2.24 & -28.62 & 2.67 & -25.32 & & \\
\hline Notonecta glauca 3 & 1 & Het & $\mathrm{C}$ & 10.33 & -32.07 & 2.50 & -28.91 & & \\
\hline Notonecta glauca 4 & 1 & Het & c & 8.19 & -34.70 & 2.29 & -29.19 & 1.01 & -28.05 \\
\hline Ilyocoris cimicoides 1 & 1 & Het & $\mathrm{C}$ & 0.73 & -25.26 & 0.66 & -28.21 & -0.05 & -24.58 \\
\hline Ilyocoris cimicoides 2 & 1 & Het & $\mathrm{C}$ & 0.46 & -24.80 & & & & \\
\hline Nepa cinerea & 1 & Het & $\mathrm{c}$ & 4.68 & -27.61 & & & & \\
\hline Ranatra linearis & 1 & Het & $\mathrm{C}$ & 4.15 & -30.30 & 6.65 & -26.18 & & \\
\hline Gerris spec. & & Het & $\mathrm{c}$ & & & 1.76 & -25.49 & & \\
\hline Acilius canaliculatus 1 & 1 & Col & $\mathrm{C}$ & 2.26 & -33.89 & 4.08 & -29.93 & 2.41 & -28.68 \\
\hline Acilius canaliculatus 2 & 1 & Col & $\mathrm{C}$ & 2.19 & -28.85 & 3.67 & -28.93 & & \\
\hline Acilius canaliculatus 3 & 1 & Col & $\mathrm{C}$ & 3.41 & -31.14 & & & & \\
\hline Acilius canaliculatus 4 & 1 & Col & c & 2.24 & -28.71 & & & & \\
\hline Acilius canaliculatus 5 & 1 & Col & c & 6.31 & -28.82 & & & & \\
\hline Acilius canaliculatus 6 & 1 & Col & $\mathrm{C}$ & 3.13 & -27.25 & & & & \\
\hline Acilius sulcatus 1 & 1 & Col & $\mathrm{C}$ & 1.77 & -30.33 & 2.21 & -29.19 & & \\
\hline Acilius sulcatus 2 & 1 & Col & $\mathrm{C}$ & 1.74 & -29.77 & & & & \\
\hline Acilius sulcatus 3 & 1 & Col & c & 2.04 & -32.55 & & & & \\
\hline Acilius sulcatus 4 & 1 & Col & $\mathrm{C}$ & 3.80 & -30.75 & & & & \\
\hline Acilius sulcatus 5 & 1 & Col & c & 4.28 & -30.03 & & & & \\
\hline Acilius sulcatus 6 & 1 & Col & $\mathrm{C}$ & 1.89 & -31.22 & & & & \\
\hline Dytiscus dimidiatus 1 & 1 & Col & $\mathrm{C}$ & 4.24 & -29.00 & 5.33 & -29.11 & & \\
\hline
\end{tabular}


Dytiscus dimidiatus 2

Dytiscus lapponicus 3

Dytiscus lapponicus 4

Dytiscus lapponicus 5

Graphoderus cinereus

Hyphydrus ovatus

Ilybius subaeneus

Gyrinus spec.

Dytiscidae larvae

Sialis spec. larvae

Chaoborus spec. larvae

Ablabesmyia spec. larvae

Polycentropodidae larvae

Argyroneta aquatica (small)

Argyroneta aquatica (large)

Hydracarina

Asellus aquaticus

Leptophlebia vespertina nymphs

Psectrocladius spec. larvae

Chironominae larvae

Chironomus spec. larvae

Phalacrocera replicata larvae

Sigara scotti

Sigara semistriata

Hesperocorixa linnei

Hesperocorixa sahlbergi

Glaenocorisa propinqua

Corixa dentipes

Phryganea bipunctata larvae

Zooplankton

\begin{tabular}{|c|c|c|c|c|c|}
\hline 5.50 & -28.37 & 3.64 & -30.60 & 2.63 & -38.57 \\
\hline 1.97 & -29.83 & 1.87 & -29.24 & & \\
\hline \multirow[t]{4}{*}{0.94} & -29.84 & 1.84 & -29.12 & & \\
\hline & & 1.84 & -28.97 & & \\
\hline & & & & 0.62 & -28.10 \\
\hline & & & & 0.23 & -27.03 \\
\hline 0.95 & -31.24 & 0.35 & -26.54 & & \\
\hline \multirow[t]{5}{*}{3.89} & -32.47 & & & & \\
\hline & & & & 0.40 & -24.33 \\
\hline & & & & -1.13 & -29.94 \\
\hline & & 2.51 & -29.90 & & \\
\hline & & & & -0.33 & -28.24 \\
\hline 1.30 & -27.93 & 0.59 & -27.68 & 1.30 & -28.19 \\
\hline \multirow[t]{5}{*}{2.67} & -27.57 & 2.97 & -25.81 & 2.10 & -24.76 \\
\hline & & 3.07 & -28.91 & & \\
\hline & & & & 3.78 & -27.88 \\
\hline & & & & -1.22 & -26.53 \\
\hline & & -1.12 & -28.70 & -1.12 & -25.94 \\
\hline-1.56 & -24.25 & & & & \\
\hline \multirow[t]{3}{*}{0.56} & -26.28 & & & & \\
\hline & & & & -2.04 & -28.43 \\
\hline & & -0.37 & -27.27 & -0.12 & -25.32 \\
\hline \multirow[t]{3}{*}{0.48} & -29.17 & & & -1.40 & -28.61 \\
\hline & & & & -0.45 & -26.17 \\
\hline & & & & 2.04 & -29.19 \\
\hline 2.66 & -30.24 & & & & \\
\hline 1.35 & -31.20 & & & & \\
\hline 1.50 & -30.33 & & & -1.07 & -30.63 \\
\hline 0.07 & -26.62 & & & -0.39 & -26.27 \\
\hline-0.94 & -33.27 & & & 2.81 & -31.36 \\
\hline
\end{tabular}




\begin{tabular}{l|rr}
\hline Species & $\mathbf{\delta}^{\mathbf{1 5}} \mathbf{N}$ & $\boldsymbol{\delta}^{\mathbf{1 3}} \mathbf{C}$ \\
\hline Enallagma cyathigerum & 2.90 & -33.64 \\
Trichoptera & 2.66 & -31.48 \\
Trichoptera & 3.65 & -30.48 \\
Nematocera & 2.08 & -30.43 \\
Trichoptera (Leptoceridae) & 2.28 & -29.72 \\
Lepidoptera larva & -3.50 & -28.55 \\
Lepidoptera (moth) & -4.32 & -28.20 \\
Lycosidae & 2.10 & -27.84 \\
Trichoptera (Limnephilus spec.) & 1.22 & -27.77 \\
Tetragnatha spec. & 2.37 & -27.76 \\
Phyralidae & 2.96 & -27.74 \\
Lycosidae & 1.91 & -27.53 \\
Lepidoptera (moth) & 0.71 & -27.23 \\
Sympetrum danae & 0.50 & -27.00 \\
Brachycera & 4.33 & -26.88 \\
Diplopoda & -2.88 & -26.86 \\
Nabidae & -1.11 & -26.77 \\
Hippodomia spec. & 0.04 & -26.75 \\
Aranaeidae & 2.98 & -26.56 \\
Bombus jonellus & -0.59 & -26.41 \\
Trichoptera (Limnephilus spec.) & -1.04 & -26.34 \\
Pterostichus minor & -0.40 & -26.24 \\
Metrioptera brachyptera & -4.34 & -26.19 \\
Thomisidae & 4.08 & -26.00 \\
Formica spec. & 0.51 & -25.73 \\
Lepidoptera larva & -4.29 & -25.43 \\
Proclossiana eunomia & -8.67 & -25.40 \\
Calliphoridae & 7.10 & -24.98 \\
Muscidae - Coenosiinae & 4.60 & -24.69 \\
Limoniinae & 2.41 & -24.34 \\
\hline
\end{tabular}




\begin{tabular}{llll}
\hline & \multicolumn{1}{c}{ Omnivores } & \multicolumn{1}{c}{ Carnivores } & Herbi-detritivores \\
\hline SOM & $0.10(0-0.37)$ & $0.09(0-0.33)$ & $0.14(0-0.47)$ \\
DOC & $0.14(0-0.49)$ & $0.13(0-0.44)$ & $0.18(0-0.63)$ \\
Sphagnum & $0.09(0-0.33)$ & $0.08(0-0.29)$ & $0.12(0-0.42)$ \\
Vascular plants & $0.11(0-0.38)$ & $0.10(0-0.34)$ & $0.14(0-0.49)$ \\
Periphyton & $0.49(0.37-0.60)$ & $0.55(0.44-0.65)$ & $0.34(0.18-0.49)$ \\
Green algae & $0.07(0-0.24)$ & $0.06(0-0.21)$ & $0.09(0-0.30)$ \\
\hline
\end{tabular}




\begin{tabular}{|c|c|c|c|c|c|c|c|c|c|c|c|c|c|}
\hline \multirow[b]{2}{*}{ PLFA } & \multirow[b]{2}{*}{ SOM } & \multirow[b]{2}{*}{$\begin{array}{c}\text { Zoo- } \\
\text { plankton }\end{array}$} & \multicolumn{2}{|c|}{ Zygoptera nymphs } & \multicolumn{2}{|c|}{ Anisoptera nymphs } & \multicolumn{3}{|c|}{ Adult Heteroptera } & \multicolumn{3}{|c|}{ Adult Coleopetera } & \multirow{2}{*}{$\begin{array}{c}\text { Midge larvae } \\
\text { Chaoborus } \\
\text { spec. }\end{array}$} \\
\hline & & & $\begin{array}{c}\text { Enallagma } \\
\text { cyathigerum }\end{array}$ & $\begin{array}{l}\text { Lestes } \\
\text { sponsa }\end{array}$ & $\begin{array}{c}\text { Leucorrhinia } \\
\text { albifrons }\end{array}$ & $\begin{array}{c}\text { Aeshna } \\
\text { juncea }\end{array}$ & $\begin{array}{c}\text { Corixa } \\
\text { dentipes }\end{array}$ & $\begin{array}{c}\text { Cymatia } \\
\text { bonsdorffii }\end{array}$ & $\begin{array}{c}\text { Notonecta } \\
\text { lutea }\end{array}$ & $\begin{array}{l}\text { Ilybius } \\
\text { aenescens }\end{array}$ & $\begin{array}{l}\text { Ilybius } \\
\text { guttiger }\end{array}$ & $\begin{array}{c}\text { Laccophilus } \\
\text { poecilus }\end{array}$ & \\
\hline \multicolumn{14}{|c|}{ Methane Oxydizing Bacteria Type 1} \\
\hline $16: 1 \omega 8 \mathrm{c}$ & 0.5 & & 0.0 & 0.0 & 0.1 & 0.2 & 0.2 & 0.1 & 0.1 & 0.0 & 0.1 & 0.1 & \\
\hline $16: 1 \omega 5 \mathrm{t}$ & 0.5 & 1.1 & 0.2 & 0.2 & 0.3 & 0.2 & 0.7 & 0.6 & 0.3 & 0.3 & 0.5 & 0.4 & 0.6 \\
\hline Total & 1.1 & 1.1 & 0.2 & 0.3 & 0.4 & 0.4 & 0.9 & 0.7 & 0.4 & 0.3 & 0.6 & 0.5 & 0.6 \\
\hline \multicolumn{14}{|c|}{ Methane Oxydizing Bacteria Type 2} \\
\hline $18: 1 \omega 8 \mathrm{c}$ & 2.6 & & & & & & & & & & & & \\
\hline \multicolumn{14}{|c|}{ Methyl-branched } \\
\hline $10 \mathrm{Me} 16: 0$ & 1.9 & & & & & & & & & & 0.0 & & \\
\hline 10Me17:0 & 0.3 & 0.2 & & & 0.2 & & & & & & & & \\
\hline $10 \mathrm{Me} 18: 0$ & 0.6 & & 0.2 & & & 0.1 & 0.1 & & 0.1 & & & 0.1 & 0.3 \\
\hline Total & 2.8 & 0.2 & 0.2 & 0.0 & 0.2 & 0.1 & 0.1 & 0.0 & 0.1 & 0.0 & 0.0 & 0.1 & 0.3 \\
\hline \multicolumn{14}{|c|}{ Branched unsaturated } \\
\hline $\mathrm{i} 17: 1 \omega 7 \mathrm{c}$ & 0.2 & 0.4 & & & & & & & & & & & \\
\hline \multicolumn{14}{|c|}{ Branched saturated } \\
\hline $\mathrm{i} 14: 0$ & 0.7 & 0.1 & & & 0.2 & & & 0.1 & & & & & \\
\hline $\mathrm{i} 15: 0$ & 3.9 & 0.3 & 0.2 & & 0.1 & & 0.2 & 0.2 & & & & 0.2 & 0.2 \\
\hline a15:0 & 4.1 & 0.2 & & & & & & & & & & & \\
\hline i16:0 & 1.5 & 0.2 & 0.1 & & & 0.2 & 0.2 & 0.5 & 0.4 & & 0.1 & 0.3 & 0.3 \\
\hline a17:0 & 1.1 & 0.3 & 0.1 & 0.1 & 0.2 & 0.2 & 0.4 & 0.4 & 0.1 & & 0.1 & 0.2 & 0.4 \\
\hline br17:0 & 0.2 & 0.1 & & & & & 0.1 & 0.1 & 0.2 & & 0.1 & 0.1 & 0.2 \\
\hline Total & 11.6 & 1.2 & 0.4 & 0.1 & 0.5 & 0.4 & 0.9 & 1.4 & 0.7 & 0.0 & 0.4 & 0.8 & 1.0 \\
\hline \multicolumn{14}{|c|}{ With cyclopropyl rings } \\
\hline cy $17: 0$ & & 1.1 & & 0.4 & & & 0.4 & & 1.0 & 0.4 & 0.6 & & 0.5 \\
\hline cy 19:0 & 7.8 & 0.2 & 1.1 & & 0.9 & 0.8 & 1.4 & 0.7 & 0.6 & 0.3 & 0.5 & 0.4 & 0.5 \\
\hline Total & 7.8 & 1.3 & 1.1 & 0.4 & 0.9 & 0.8 & 1.8 & 0.7 & 1.6 & 0.7 & 1.1 & 0.4 & 1.0 \\
\hline \multicolumn{14}{|c|}{ Polyunsaturated } \\
\hline $18: 2 \omega 6 c, 9 c$ & & & 0.2 & & & & 0.1 & & 18.2 & 24.5 & 21.4 & 0.1 & \\
\hline $18: 2 \omega 6 \mathrm{c}, 12 \mathrm{c}$ & 0.4 & & & & & & & & & & & & \\
\hline $18: 2 \omega 7 \mathrm{c}, 12 \mathrm{c}$ & 0.5 & & & & 0.2 & & 0.1 & & & & & & \\
\hline $18: 3 \omega 4$ & 1.9 & 0.2 & & & 0.3 & & & & & & & & \\
\hline $18: 3 \omega 6$ & 0.3 & & 9.9 & 11.4 & 10.7 & 6.9 & 7.4 & 7.2 & 4.7 & 10.3 & 7.9 & 4.0 & 10.0 \\
\hline $20: 4 \omega ?$ & 0.8 & 1.2 & 14.4 & 9.2 & 14.7 & 18.5 & 13.5 & 20.9 & 13.2 & 9.3 & 12.1 & 24.0 & 7.4 \\
\hline
\end{tabular}




\begin{tabular}{|c|c|c|c|c|c|c|c|c|c|c|c|c|c|}
\hline $20: 5 \omega 3$ & 0.6 & 3.9 & 14.3 & 16.8 & 13.6 & 10.9 & 20.2 & 16.8 & 11.3 & 8.4 & 9.7 & 14.1 & 22.6 \\
\hline Total & 4.5 & 5.2 & 38.8 & 37.3 & 39.5 & 36.3 & 41.4 & 44.9 & 47.4 & 52.6 & 51.2 & 42.2 & 39.9 \\
\hline \multicolumn{14}{|c|}{ Monounsaturated } \\
\hline $16: 1 \omega 9 t$ & & 0.1 & & & & & 0.1 & & & & & & 0.2 \\
\hline $16: 1 \omega 9 \mathrm{c}$ & 0.6 & & & & 0.6 & 0.1 & & 0.3 & & & & 0.1 & \\
\hline $16: 1 \omega 7 \mathrm{c}$ & 4.2 & 10.0 & 1.6 & 1.2 & 2.0 & 1.8 & 3.6 & 2.8 & 2.3 & 1.7 & 2.4 & 5.9 & 2.2 \\
\hline $16: 1 \omega 6 \mathrm{c}$ & 0.7 & & 0.2 & 0.2 & 0.2 & 0.3 & 0.4 & 0.4 & 0.1 & & 0.2 & 0.3 & 0.3 \\
\hline $16: 1 \omega 5 \mathrm{c}$ & 0.6 & 0.2 & 0.1 & & 0.1 & 0.2 & 0.2 & & & & 0.1 & 0.2 & 0.2 \\
\hline $17: 1 \omega 6 \mathrm{c}$ & 0.4 & 0.3 & 0.1 & & 0.1 & 0.2 & 0.2 & 0.4 & 0.3 & & & 0.2 & 0.1 \\
\hline $18: 1 \omega 11 \mathrm{t}$ & 0.9 & 0.3 & & & 0.2 & & & 0.3 & & & & & \\
\hline $18: 1 \omega 9 \mathrm{c}$ & 5.3 & 10.6 & 20.6 & 21.6 & 21.8 & 23.5 & 21.3 & 17.3 & 23.6 & 24.3 & 24.6 & 20.1 & 18.4 \\
\hline $18: 1 \omega 9 t$ & 1.6 & 0.1 & & & 0.2 & & & & & & & & \\
\hline $18: 1 \omega 7 \mathrm{c}$ & 31.0 & 7.2 & 8.6 & 8.3 & 6.8 & 8.6 & 6.2 & 5.7 & 2.3 & 1.3 & 2.4 & 3.8 & 4.6 \\
\hline $18: 1 \omega 5 \mathrm{c}$ & 0.2 & & & & 0.1 & 0.2 & 0.1 & & & & & & \\
\hline $20: 1 \omega ?$ & 0.3 & 0.3 & & 0.3 & 0.4 & 0.2 & 0.2 & 0.2 & 0.1 & 0.3 & 0.2 & 0.2 & 0.2 \\
\hline Total & 45.7 & 29.2 & 31.2 & 31.6 & 32.6 & 35.2 & 32.3 & 27.3 & 28.7 & 27.6 & 29.9 & 30.7 & 26.1 \\
\hline \multicolumn{14}{|l|}{ Saturated } \\
\hline $14: 0$ & 2.0 & 6.6 & 0.2 & 0.1 & 0.3 & 0.2 & 0.3 & 0.4 & 0.2 & 0.1 & 0.3 & 0.4 & 0.9 \\
\hline $15: 0$ & 0.5 & 2.3 & 0.3 & 0.3 & 0.3 & 0.3 & 0.3 & 0.3 & 0.2 & & 0.2 & 0.3 & 0.6 \\
\hline $16: 0$ & 14.4 & 41.4 & 14.5 & 17.6 & 11.6 & 10.7 & 9.4 & 8.8 & 11.2 & 12.8 & 10.9 & 13.1 & 21.0 \\
\hline $17: 0$ & 0.8 & 1.5 & 0.2 & 0.2 & 0.2 & 0.3 & 0.3 & 1.8 & & & 0.1 & 0.2 & 0.4 \\
\hline 18:0 & 3.9 & 8.2 & 11.7 & 10.4 & 12.9 & 14.0 & 12.1 & 12.5 & 8.3 & 5.3 & 4.8 & 10.2 & 7.6 \\
\hline $20: 0$ & 0.2 & 0.4 & 0.2 & & & & & & & & & & \\
\hline $22: 0$ & 1.4 & 0.2 & & & & & & & & & & & \\
\hline Total & 23.2 & 60.6 & 27.1 & 28.6 & 25.2 & 25.4 & 22.2 & 23.7 & 19.9 & 18.2 & 16.3 & 24.2 & 30.5 \\
\hline \multicolumn{14}{|c|}{ Estimated chain length } \\
\hline ECL17.344 & 0.3 & & 0.5 & & 0.5 & 0.8 & & 0.7 & & & & 0.6 & \\
\hline ECL17.311 & 0.6 & & & & 0.7 & & & & & & & & \\
\hline ECL17.392 & 0.1 & 0.1 & & & 0.3 & & & & & & & & \\
\hline ECL17.488 & & & & & & & & 0.1 & 0.5 & & & & \\
\hline ECL17.844 & & & & & & & & & 0.2 & & & & \\
\hline Total & 1.0 & 0.1 & 0.5 & 0.0 & 1.4 & 0.8 & 0.0 & 0.8 & 0.7 & 0.0 & 0.0 & 0.6 & 0.0 \\
\hline Bacterial total* & 57.1 & 11.4 & 10.4 & 9.2 & 8.8 & 10.3 & 9.9 & 8.4 & 5.0 & 2.3 & 4.4 & 5.6 & 7.5 \\
\hline
\end{tabular}




\begin{tabular}{|c|c|c|c|c|c|c|c|c|c|c|c|c|c|}
\hline \multirow[b]{2}{*}{ PLFA } & \multirow[b]{2}{*}{ SOM } & \multirow[b]{2}{*}{$\begin{array}{c}\text { Zoo- } \\
\text { plankton }\end{array}$} & \multicolumn{2}{|c|}{ Zygoptera larvae } & \multicolumn{2}{|c|}{ Anisoptera larvae } & \multicolumn{3}{|c|}{ Adult Heteroptera } & \multicolumn{3}{|c|}{ Adult Coleoptera } & \multirow{2}{*}{$\begin{array}{c}\text { Midge larvae } \\
\text { Chaoborus } \\
\text { spec. }\end{array}$} \\
\hline & & & $\begin{array}{c}\text { Enallagma } \\
\text { cyathigerum }\end{array}$ & $\begin{array}{l}\text { Lestes } \\
\text { sponsa }\end{array}$ & $\begin{array}{c}\text { Leucorrhinia } \\
\text { albifrons }\end{array}$ & $\begin{array}{c}\text { Aeshna } \\
\text { juncea }\end{array}$ & $\begin{array}{c}\text { Corixa } \\
\text { dentipes }\end{array}$ & $\begin{array}{c}\text { Cymatia } \\
\text { bonsdorffii }\end{array}$ & $\begin{array}{c}\text { Notonecta } \\
\text { lutea }\end{array}$ & $\begin{array}{c}\text { Ilybius } \\
\text { aenescens }\end{array}$ & $\begin{array}{l}\text { Ilybius } \\
\text { guttiger }\end{array}$ & $\begin{array}{c}\text { Laccophilus } \\
\text { poecilus }\end{array}$ & \\
\hline $14: 0$ & -32.6 & -37.4 & & & & & & & & & & & \\
\hline i15:0 & -35.5 & & & & & & & & & & & & \\
\hline a15:0 & -33.8 & & & & & & & & & & & & \\
\hline $15: 0$ & & -29.5 & & & & & & & & & & & \\
\hline i16:0 & -29.9 & & & & & & & & & & & & \\
\hline $16: 0$ & -32.6 & -36.3 & -33.4 & -34.8 & -33.4 & -33.3 & -34.1 & -34.8 & -32.5 & -32.0 & -32.8 & -32.9 & -36.9 \\
\hline $16: 1 \omega 7 \mathrm{c}$ & -36.7 & -27.9 & -31.3 & -32.7 & -32.1 & -37.2 & -40.4 & -31.2 & -33.0 & -32.7 & -33.8 & -33.4 & -37.6 \\
\hline 10Me16:0 & -34.4 & & & & & & & & & & & & \\
\hline a17:0 & -31.4 & & & & & & & & & & & & \\
\hline $17: 0$ & -35.1 & -41.4 & & & & & & -34.1 & & & & & \\
\hline cy $17: 0$ & & -38.5 & & & & & & & -35.6 & & & & \\
\hline $18: 0$ & -31.0 & -38.0 & -32.5 & -34.8 & -33.2 & -32.1 & -33.8 & -34.1 & -32.3 & -30.8 & -31.7 & -32.4 & -38.1 \\
\hline $18: 1 \omega 11 \mathrm{t}$ & -35.5 & & & & & & & & & & & & \\
\hline $18: 1 \omega 9 \mathrm{c}$ & -32.5 & -30.6 & -33.3 & -34.1 & -33.4 & -32.5 & -34.4 & -34.5 & -32.5 & -31.3 & -32.8 & -32.8 & -36.4 \\
\hline $18: 1 \omega 9 \mathrm{t}$ & -35.6 & & & & & & & & & & & & \\
\hline $18: 1 \omega 8 \mathrm{c}$ & -38.0 & & & & & & & & & & & & \\
\hline $18: 1 \omega 7 \mathrm{c}$ & -35.3 & -30.6 & -33.2 & -33.2 & -33.5 & -31.7 & -35.9 & -31.6 & -33.5 & -32.9 & -29.8 & -33.7 & -34.4 \\
\hline $18: 2 \omega 6 c, 9 c$ & & & & & & & & & -32.7 & -32.9 & -33.1 & & \\
\hline $18: 3 \omega 6$ & & & -40.5 & -41.4 & -37.5 & -39.5 & -37.2 & -42.3 & -37.5 & -39.2 & -40.6 & -40.3 & -40.9 \\
\hline $18: 3 \omega 4$ & -34.2 & & & & & & & & & & & & \\
\hline cy19:0 & -35.6 & & -32.3 & & & & -37.6 & & & & & & \\
\hline $20: 4 \omega ?$ & -45.5 & -47.1 & -33.6 & -39.3 & -33.2 & -34.2 & -36.7 & -36.5 & -34.0 & -34.2 & -35.4 & -34.5 & -40.3 \\
\hline $20: 5 \omega 3$ & -30.6 & -34.5 & -37.1 & -37.2 & -36.0 & -34.0 & -32.1 & -39.2 & -35.3 & -34.8 & -37.4 & -37.2 & -36.2 \\
\hline
\end{tabular}




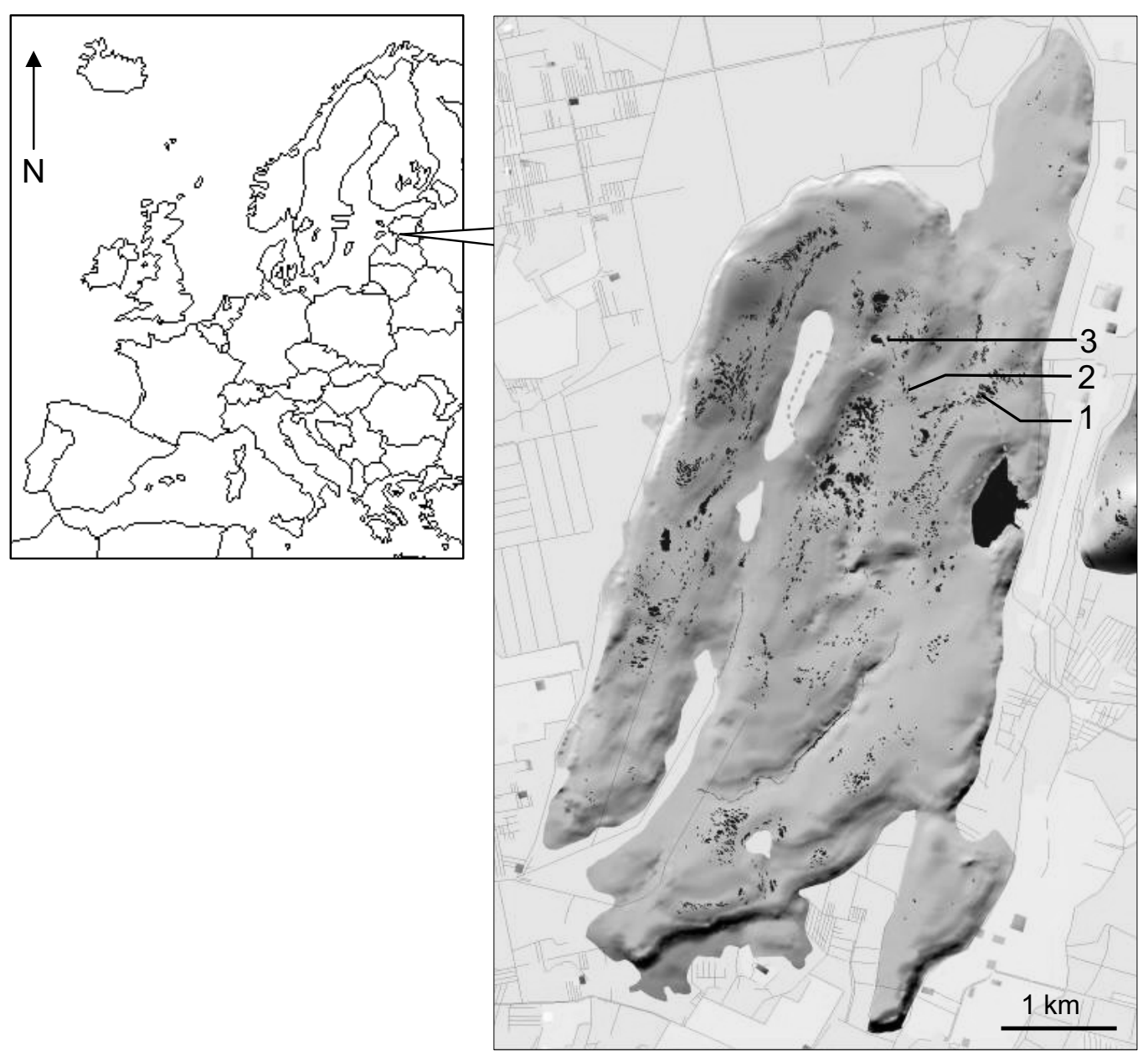




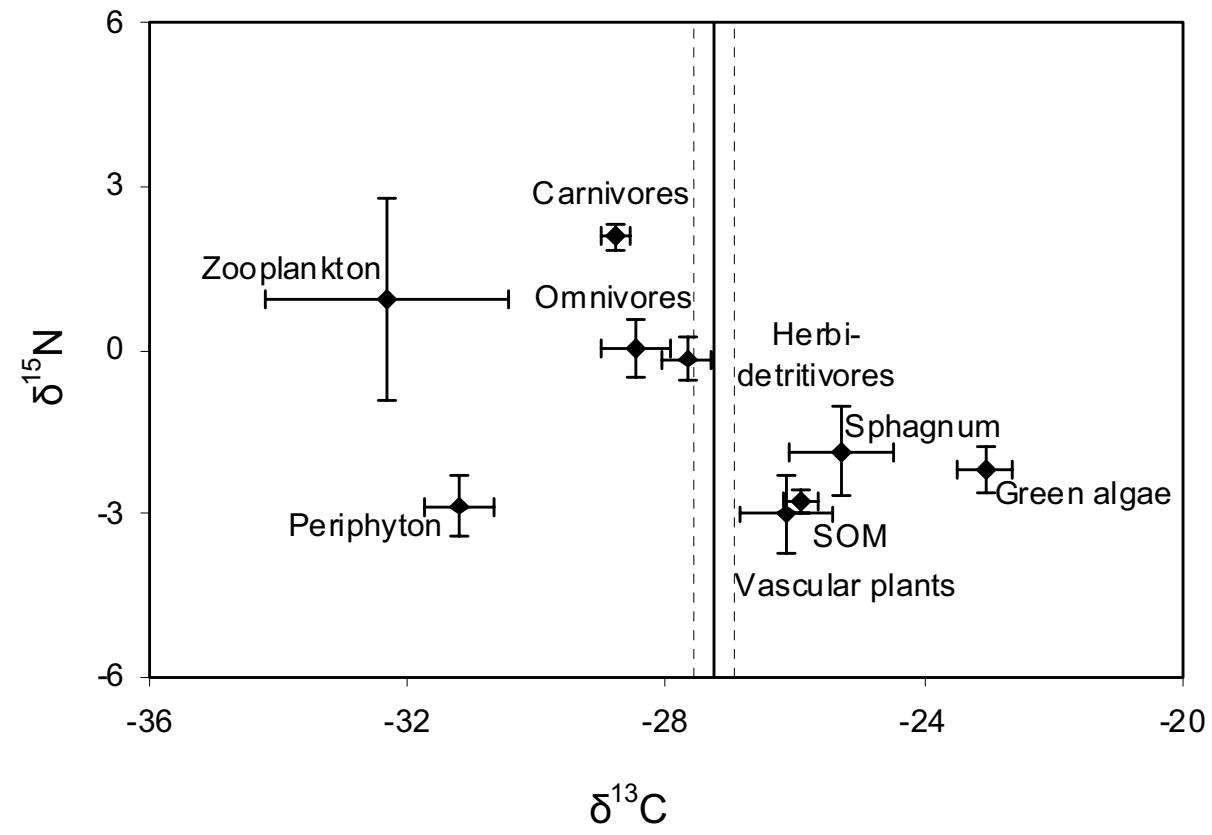




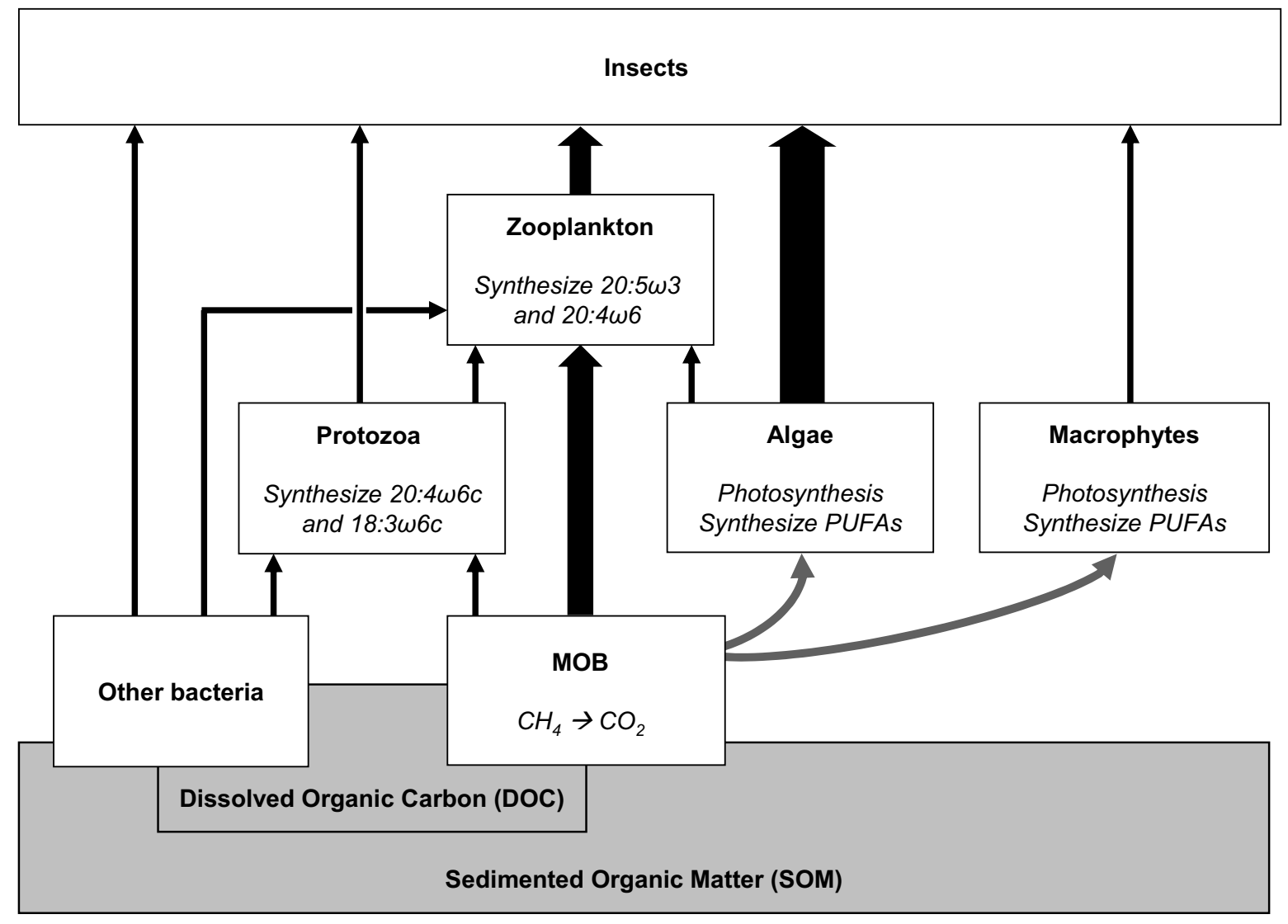

